\title{
Green Catalysts: Applied and Synthetic Photosynthesis ${ }^{+}$
}

\author{
Alexandra H. Teodor ${ }^{1}$, Benjamin D. Sherman ${ }^{2}$, Zeah Yvette Ison ${ }^{3}$, Eu-Jee Ooi ${ }^{3}$, \\ Jesse J. Bergkamp ${ }^{3}$ and Barry D. Bruce ${ }^{1,4,5, * \mathbb{D}}$ \\ 1 Graduate School of Genome Science and Technology, University of Tennessee at Knoxville and Oak Ridge \\ National Laboratory, Knoxville, TN 37916, USA; ateodor@vols.utk.edu \\ 2 Department of Chemistry and Biochemistry, Texas Christian University, Fort Worth, TX 76129, USA; \\ B.D.SHERMAN@tcu.edu \\ 3 Department of Chemistry and Biochemistry, California State University Bakersfield, \\ Bakersfield, CA 93311, USA; zison@csub.edu (Z.Y.I.); eooi@csub.edu (E.-J.O.); jbergkamp@csub.edu (J.J.B.) \\ 4 Department of Chemical and Biomolecular Engineering, University of Tennessee at Knoxville, \\ Knoxville, TN 37996, USA \\ 5 Biochemistry, Cellular \& Molecular Biology Department, University of Tennessee at Knoxville, \\ Knoxville, TN 37916, USA \\ * Correspondence: bbruce@utk.edu; Tel.: +1-865-974-4082 \\ + This contribution is dedicated to Ana and Tom Moore: Mentors, Colleagues, Friends, and Early Visionaries.
}

Received: 8 August 2020; Accepted: 1 September 2020; Published: 3 September 2020 check for

\begin{abstract}
The biological process of photosynthesis was critical in catalyzing the oxygenation of Earth's atmosphere 2.5 billion years ago, changing the course of development of life on Earth. Recently, the fields of applied and synthetic photosynthesis have utilized the light-driven protein-pigment supercomplexes central to photosynthesis for the photocatalytic production of fuel and other various valuable products. The reaction center Photosystem I is of particular interest in applied photosynthesis due to its high stability post-purification, non-geopolitical limitation, and its ability to generate the greatest reducing power found in nature. These remarkable properties have been harnessed for the photocatalytic production of a number of valuable products in the applied photosynthesis research field. These primarily include photocurrents and molecular hydrogen as fuels. The use of artificial reaction centers to generate substrates and reducing equivalents to drive non-photoactive enzymes for valuable product generation has been a long-standing area of interest in the synthetic photosynthesis research field. In this review, we cover advances in these areas and further speculate synthetic and applied photosynthesis as photocatalysts for the generation of valuable products.
\end{abstract}

Keywords: photosynthesis; photoelectrochemical devices; biohybrid; synthetic biology; photochemistry; photoelectrochemistry; hydrogen evolution

\section{Introduction}

The generation of electricity through renewable, sustainable means is a crucial step for meeting future anthropocentric energy demands. Several renewable energy technologies have been utilized, such as wind, geothermal, hydroelectric, and wave/tide generators. However, these technologies are dependent on local resources and are therefore location limited. One energy resource that is of great interest and abundantly widespread is solar energy that can be captured through photovoltaics technology. Converting solar energy via applied and synthetic photosynthesis could lower society's dependence on fossil fuels. However, the overwhelming majority of current photovoltaics in use today are crystalline silicon solar cells, part of the first generation of photovoltaic technologies. These utilize rare and precious metals in their materials that require specific recycling requirements, and 
are estimated to generate over 50 million tons of waste by 2050. Clearly, further improvement on current photovoltaic technology is necessary for the future. Applied photosynthesis, being studied as an emerging photovoltaic technology, takes inspiration from and utilizes the fundamental mechanisms and components that nature has already developed for biological photosynthesis, specifically the light reactions of biological photosynthesis.

Incorporating biological light-absorbing pigments into otherwise man-made devices is an attractive approach for converting solar energy into electric potential or fuels due to their high internal quantum efficiency of charge separation, non-toxic nature, and carbon-neutral production. One such device is the dye-sensitized solar cell (DSSC), part of the third generation of photovoltaic technologies being developed that has been of great interest to researchers. The fundamental charge generation processes in DSSCs are similar to those found in natural photosynthesis, and are as follows: a chromophore absorbs a photon, producing the dye excited state. The excited state transfers an electron to an n-type semiconductor support, which results in current flow from the photoanode to cathode in the cell. The resulting surface-oxidized dye regenerates the ground state by electron transfer from a reduced redox mediator in solution, and the oxidized form of the mediator is then re-reduced at the cathode to complete the electric circuit of the cell. This process allows the stable conversion of photon energy to electric potential energy, which could also be used to drive net catalytic redox reactions to give a photoelectrosynthetic cell in place of a photovoltaic device, such as a DSSC. In Figure 1 below, the key components necessary for a biohybrid photoelectrosynthetic cell are shown.

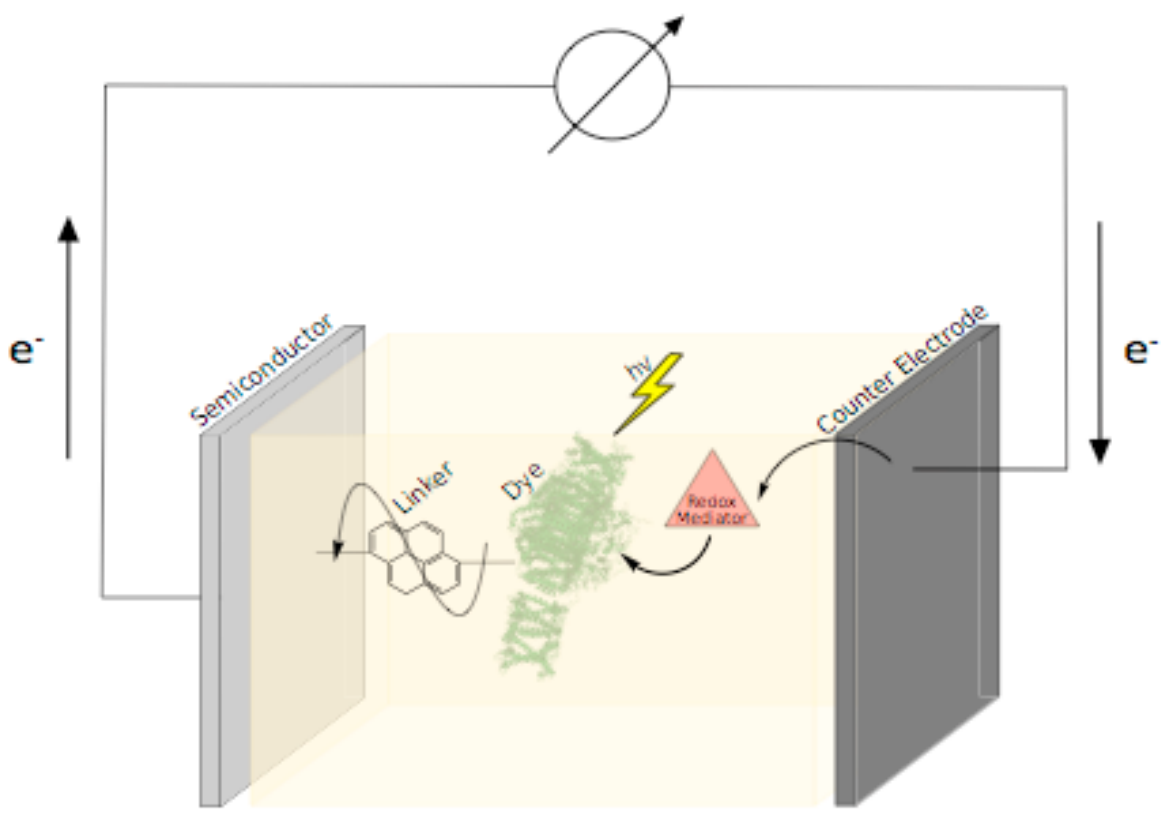

Figure 1. General schematic showing the key working components of a biohybrid photoelectrosynthetic cell. The figure shows a bio-absorber (dye), after light excitation donating an electron through a linker to a semiconductor surface. This electron is then passed to the counter electrode where it interacts with a redox mediator that reduces the oxidized bio-absorber and completes the circuit.

Similarly, the first stage of photosynthesis requires a photon to be absorbed by pigments bound within protein complexes in a light-harvesting antenna, promotion of an electron to an excited state and then subsequent charge separation followed by multiple electron-transfer steps. Reaction centers such as Photosystem I (PSI), Photosystem II (PSII), and bacterial reaction centers from organisms such as the purple bacterium Rhodobacter sphaeroides (R. sphaeroides) are examples of such protein-pigment supercomplexes, and they operate at internal quantum efficiencies approaching $100 \%$. PSII performs the biological oxidation of water at $+1.2 \mathrm{~V}$ vs. SHE utilizing a $\mathrm{Mn}_{4} \mathrm{O}_{5} \mathrm{Ca}$ oxygen-evolving complex to generate electrons. In turn, PSI generates the greatest reducing potential found in nature of $-1.2 \mathrm{~V}$ 
vs. SHE, yielding highly reducing electrons which go on to power ATP and NADH generation along with carbon fixation in vivo in photosynthetic organisms. Reaction centers perform their primary charge separation activity via a special pair of pigments. In PSI, this charge separation occurs with an exceptionally high quantum efficiency of near $100 \%$, far above that of many synthetic photosensitizers utilized in inorganic DSSCs, and an electron transfer rate reported to approach $50 \mathrm{e}^{-} \mathrm{s}^{-1} \mathrm{PSI}^{-1}$ in vivo [1]. Further, PSI and other biological photosensitizers are relatively low cost and carbon neutral to produce, with easy waste management as compared to other photosensitizers, making them of interest for the generation of carbon-neutral, sustainable devices [2].

Another area of interest for the generation of fuels and other valuable products takes inspiration from the biological photocatalytic process of photosynthesis, that of synthetic photosynthesis. Instead of utilizing biological materials such as pigments or reaction centers for performing the initial conversion of photonic to electronic energy that are then incorporated into inorganic devices, synthetic man-made reaction centers perform the initial conversion of photonic energy which are then coupled to drive non-photoactive biological enzymes for product generation. Since this biohybrid uses non-toxic and highly selective enzymes and takes advantage of their high catalytic turnover rates, this area is of increasing interest for the sustainable generation of valuable chemical products. This approach is similar to photosynthetic organisms, who do not directly couple their photochemical reactions to terminal catalysis, instead performing the chemical reactions in a controlled, step-wise manner through a limited subset of reactive chemical species that power the enzymatic catalysis of substrates.

In this review, we cover recent advances and areas of focus in these two research areas of applied and synthetic photosynthesis, specifically on photocurrent and molecular hydrogen production through applied photosynthesis, and generation of valuable products through artificial photosynthesis. We also speculate on areas of improvement and future directions for these bio-inspired photocatalysis research fields.

\section{Applied Photocurrent}

This section reports the most recent advances of photocurrent generation by photosynthetic protein-pigment complexes incorporated into devices for energy or valuable product generation. We focus on the reaction centers PSI and PSII and the light-harvesting antennas Light-Harvesting Complex I (LHC I) and Light-Harvesting Complex II (LHC II) being used as the primary photocatalysts for these applications. Many advances discussed herein include the studies of electrode materials and semiconducting surfaces, redox mediators, chemical modification, and some examples of photoprotection for device stability. An overview of the electrical steps necessary for function of these photovoltaic devices is shown in Figure 2 below.

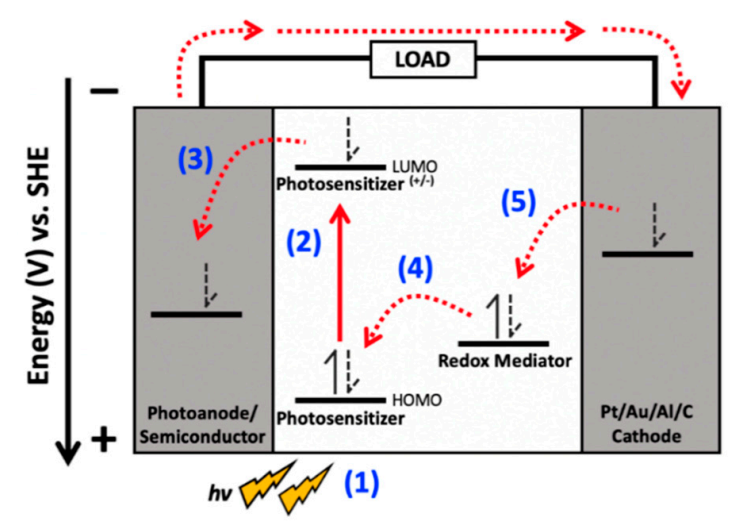

Figure 2. Representation of electron transfer in a photovoltaic device. This is comprised of a photosensitive dye(s), semiconductors, and electrolyte (redox mediator). In order for forward electron injection from a dye to a semiconductor to take place, the lowest unoccupied molecular orbital (LUMO) must have a more negative potential than the semiconductor. The electrolyte must bear a more negative 
potential then dye $\mathrm{e}^{+}$. The steps of electron transfer are as follows: (1) first, the photosensitizer (PSI) absorbs a photon, and (2) the photosensitizer is then promoted to an excited state. Next, charge separation by the photoexcited sensitizer occurs, and (3) the excited electron is injected into the conduction band of the semiconductor. (4) The photosensitizer is then reduced by the redox mediator in the electrolyte, priming it for further photoexcitation events to generate more photocurrent. Finally, (5) the redox mediator is reduced in turn at the counter electrode, completing the circuit. Adapted from [3].

\subsection{Light Absorption, Electronic Considerations, and Optical Cross Sections of Reaction Centers}

Researchers have shown that optimal energetics of electron transport pathways occur when photoactivated biohybrid energy harvesting constructs involve PSI interacting with a soluble carrier, a solid-state electrode, or bound catalysts [4]. PSI, PSII, and LHC I and II are biological supercomplexes composed of both proteinaceous subunits along with pigments and other redox-active cofactors. These protein-pigment complexes function as light absorbers and energy converters that are active over large specific regions of the UV-Visible spectrum based on the primary pigments present in their light-harvesting antennas. There is a general consensus in the applied photosynthesis field that PSI can further be modified for optimal energy conversion by modification of absorption wavelengths, which is a property of the biohybrid material, and through the incorporation of selective biocompatible electrodes, mediators, and composite matrices in systems for solar energy conversion, or photocatalysis [5]. Enhancement of the optical cross section of photosensitizers to extend their photoexcitation capabilities is one strategy of interest for increasing the output of these photocatalysts. These modifications have also been seen in nature, with photosynthetic organisms utilizing novel forms of chlorophyll pigments with unique optoelectronic properties to make use of the portion of the UV-Visible spectrum that is available to them [6]. In this section, we will focus on the progress made in the studies that include information on, or involve, light absorption and electronic considerations of reaction centers. In Figure 3 below, we show the optical cross sections of the biological reaction centers and synthetic dyes discussed in this section.

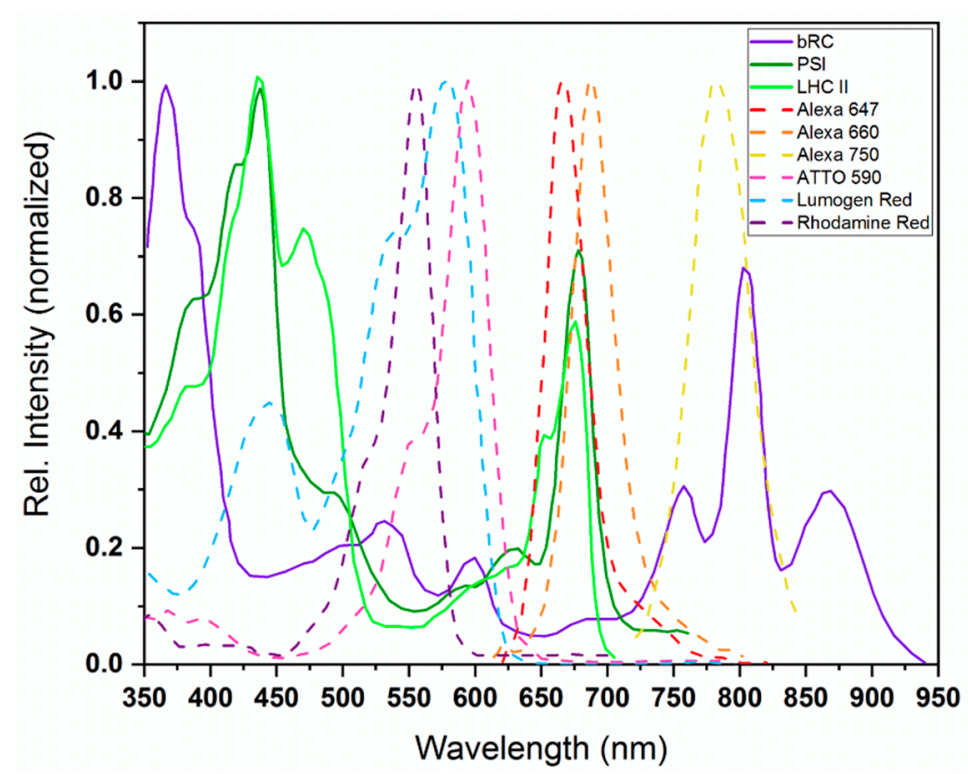

Figure 3. Optical cross sections of reaction centers and dyes. The UV-Visible absorption spectra of commonly studied biological reaction centers and dyes used to extend their optical cross sections are shown. The maxima of each spectra were normalized to 1.0 for comparison.

One research group studied the photoelectrochemistry of PSI immobilized on a photoelectrode surface and found that upon illumination with a $676 \mathrm{~nm}$ band-pass filtered light at $1.4 \mathrm{~mW} \mathrm{~cm}^{-2}$, a photocurrent of $4 \mu \mathrm{A} \mathrm{cm}^{-2}$ is obtained [7]. This $676 \mathrm{~nm}$ light is near the optimal excitation wavelength 
for PSI. However, the efficiency of PSI electron generation through the absorption of incident photons is limited by its poor absorption in the "green gap" of its absorption spectrum [8]. One approach to increase the optical cross section of reaction centers is the incorporation of synthetic dyes that absorb in different regions of the UV-Vis spectrum, enabling a transfer of energy from the dyes to the reaction center [8]. Dye-modified PSI activity has been shown to be enhanced even in solid-state devices as evident via surface photovoltage (SPV) experiments [8].

Dyes have also been conjugated to photosynthetic reaction centers and light-harvesting antennas beyond PSI in attempts to enhance their optical cross sections, and thus, their ability to be photoactivated. The use of dyes to fill in the "green gap" of chlorophyll-based protein-pigment complexes has been studied for the last decade. One of the earlier reports on modulating optical cross sections assessed synthetic porphyrin and chlorin dyes with a variety of side groups and their spectral properties and ability to self-assemble into biomimetic light-harvesting antenna systems [9]. The highly ordered nature of these dyes, similar to the order of pigments in biological protein-pigment complexes, allowed for photoexcitation even when aggregated and the photochemical efficiency was unaffected [10]. The ability to couple together different dyes in synthetic biomimetic systems to enhance light-harvesting capabilities led to interest in the conjugation of dyes to biological reaction centers such as PSI to similarly supplement their optical cross section.

One report on dyes conjugated with a biological protein-pigment complex used recombinant LHC II, a PSI and PSII light-harvesting antenna complex and either one or three Rhodamine Red dyes covalently attached via cysteine residues on the protein [11]. Dye addition did not affect the assembly, stability or activity of LHC II. While labelling efficiencies were low, electron transfer efficiency to LHC II was near $100 \%$. Other dyes that have been similarly utilized include Alexa Fluor 660, 647, and 750 dyes, yielding similarly improved photogeneration of charge separated species while maintaining protein stability [12]. To date, the dyes Lumogen Red and ATTO 590 have been utilized to fill in the "green gap" of PSI. The coupling of approximately 30 ATTO 590 dye molecules to PSI increased the oxygen consumption activity of PSI by over 4-fold, and the addition of Lumogen Red allowed for greater energy transfer to PSI via Förster resonance energy transfer. Expanding the light-harvesting capabilities of PSI through conjugation of dyes $[8,13]$ is likely to be an area of further focus for improving outputs of future reaction center-based biohybrid devices.

Artificial metal nanoparticle antennas can also be used to enhance PSI light absorption and PSI circular dichroism over the protein's entire absorption band as opposed to the utilization of spherical metal nanoparticles (NP), which enhances only specific plasmon resonance wavelengths [14]. Metal NP aggregates, due to the high dielectric constant of the metal, and NP-PSI-NP antenna junctions cause broad-resonant and non-resonant electronic field enhancements, as well as enhancing PSI's light absorption capabilities [14]. Some researchers were able to achieve a $100 \%$ quantum efficiency with an integrated photoexcited PSI in solar energy conversion devices as the photoactive electrode [15]. Ag NPs have been found to enhance chlorophyll fluorescence up to 18-fold in peridinin-chlorophyll-protein assemblies, and 5- to 20-fold for thin films of cyanobacterial PSI [16,17]. Similarly, incorporation of $\mathrm{Au}$ NPs in leaves and chloroplasts in vivo increased reaction center reduction rates [18]. While metal NPs may not directly expand optical cross sections, enhancement of the photoelectrochemical activity of reaction centers, including PSI, should lead to improved photocurrent outputs of devices. The use of metal nanostructures, such as nanopyramids [19], and NPs has been suggested to enhance photochemical activity through plasmonic coupling, and further engineering to enhance interactions of this biotic-abiotic interface is likely to be studied for further biohybrid device improvement [20].

Quantum dots (QDs) have also been incorporated with photosynthetic reaction centers in attempts to enhance their photoelectrochemical properties and activities. The optoelectronic properties of QDs are as a function of both size and shape [21], allowing for fine tuning to enhance their optical cross section. QDs have previously been shown to be capable of transferring their photoexcitation energy to reaction centers, including PSI [22,23]. Reaction center charge separation has been found to increase anywhere from 3-5-fold upon QD conjugation. A study assessing the interaction of CdTe QDs with 
the R. sphaeroides reaction center found that use of a polyhistidine tag on the reaction center allowed for targeted binding of the QD to the tag, and up to 95\% QD labeling efficiency was achieved as well [24]. The ability to now fine tune the optoelectronic as well as binding properties of QDs makes this an area with great potential for further enhancement of biological photosynthetic reaction centers as light-activated catalysts.

\subsection{Novel Semiconductor Materials, Architectures, and Electrode Surface Modifications}

There are several publications on inorganic materials and surface shape used as semiconductors for biohybrid devices in the applied photosynthesis field. By improving the interface between the biological and inorganic portions of biohybrid devices, the aim is to increase the compatibility and further improve both outputs and rates of constructive forward electron transfer in devices. In this section, we will highlight recent advances in multiple methods for enhancing photosensitizer attachment and activity with semiconductors, including covalently linking reaction centers, intermolecular forces, and electrostatics along with novel semiconductor materials and architectures.

\subsubsection{Semiconductor Materials, Architectures, and Modifications}

Novel semiconductor materials for biohybrid-based devices are of interest in the applied photosynthesis community to promote stronger affinity of the photosensitizer (PSI, PSII, bacterial reaction center) with the working electrode and enhance the biocompatability. Further, the electronic properties of the semiconductor material itself must be considered so that both charge collection and forward electron transfer from the photosensitizer reaction center occur at a rate that outcompetes the back reaction and charge recombination of the photosensitizer. Further, the conduction band of the semiconductor must be well matched for forward electron injection from the biological photosensitizer with minimal wasted energy, and electron injection into the working electrode material. The use of semiconductor materials with these properties, along with the necessary biocompatibility, has led to many research studies on this particular method of improving biohybrid device output.

One of the most commonly used and well-studied semiconductors for DSSCs in general, as well as specifically for biohybrid devices, is titanium dioxide $\left(\mathrm{TiO}_{2}\right)$. Isolated and purified biological pigments along with PSI and spinach LHCII can be spontaneously adsorbed in an active manner on three types of $\mathrm{TiO}_{2}$ films [25]. The ability to engineer $\mathrm{TiO}_{2}$ into novel semiconductor nanostructures has been well studied, as the ability to form $3 \mathrm{D}$ semiconductor architectures can dramatically increase the surface area of the electrode, permitting several orders of magnitude improvement in the amount of photosensitizer active in the biohybrid device. In addition to increased photosensitizer loading, increased contact with redox electrolytes is also achieved with 3D nanostructured semiconductor materials [26]. Some 3D structures utilized to date include $\mathrm{TiO}_{2}$ nanoparticles (NPs), nanotubes, nanopyramids, and inverse opal designs [19,27-29].

There have been reports on the use of metal-binding peptides fused onto both reaction centers and redox mediator proteins to help increase coverage on semiconductor surfaces. Subunits of PSI have been recombinantly produced with $\mathrm{ZnO}$-binding peptides (ZOBiP-PSI), and $\mathrm{TiO}_{2}$-binding peptides (TOBiP) have been fused to ferredoxin, the native biological acceptor of electrons from PSI to yield TOBiP-Fd. PSI can be chemically cross linked with TOBiP-Fd on its acceptor side, and these PSI-Fd-TOBiP fusions along with ZOBiP- and MOBiP-PSI complexes show greater affinity upon incubation with various metal oxide nanoparticles for the semiconductor materials as compared to the native protein [30]. Use of the native electron acceptor partner, ferredoxin, may also help to increase forward electron transfer rates and reduce changes of PSI charge recombination occurring.

Some novel semiconductor materials being studied include gallium arsenide, carbon nanotubes or nanoparticles, and other nanorods or nanoparticles made from $\mathrm{TiO}_{2}$, silicon, graphene, and gold. Further modification of the semiconductor surface by using conductive films composed of Nafion or Os polymers, oxides, metal nanoparticles, p-doped silicon, alkanethiolate self-assembled monolayer/Au, and graphene influence the production of photocurrent. 
One such study utilized hematite as a semiconductor material with PSI. A biophotoanode performed electronic coupling between a red algal PSI associated with its light-harvesting antenna LHCI and nanocrystalline n-typed semiconductors, such as $\mathrm{TiO}_{2}$ and hematite $\left(\alpha-\mathrm{Fe}_{2} \mathrm{O}_{3}\right)$, through a structured multilayer of PSI-LHCI over both semiconductors organized as highly ordered nanocrystalline arrays [31]. The $\alpha-\mathrm{Fe}_{2} \mathrm{O}_{3} /$ PSI-LHCI organization is prepared by immobilizing the PSI-LHCI complex with its reducing side towards the $\alpha-\mathrm{Fe}_{2} \mathrm{O}_{3}$ surface and nano structuring the multilayer in such a way to organize the subsequent complex layers in a head-to-tail orientation [31]. This biophotoanode operated at the highest quantum efficiency and generated the largest open circuit photocurrent reported to date as compared to the tandem system based on $\mathrm{TiO}_{2} / \mathrm{PSI}-\mathrm{LHCI}$ material [31].

The integration of large membrane proteins such as reaction centers into rapidly prepared composite films needs to be a controlled process. One way this can be performed is through the use of potentiostatic electropolymerization from an aqueous solution containing both polymer and PSI to prepare polymer-protein films on Au electrodes [32]. A novel preparation with poly(3,4-ethylenedioxythiophene)/single-walled carbon nanotube (PEDOT/SWCNT) composite films with $0-50$ wt.\% SWCNT contents utilized a vapor-phase polymerization technique [33]. A 35 wt. $\%$ SWCNT provides a maximum power factor of $37.8 \mu \mathrm{W} \mathrm{mK}{ }^{-2}$, which is 1.7 -fold higher than polymer-protein films prepared without SWCNTs [33].

The use of carbon-based semiconductor materials such as SWCNTs has been an area of increasing interest in the applied photosynthesis field. A high photocurrent generation and efficiency of a graphene-biohybrid light-harvesting electrode has been observed when it consisted of cyanobacterial trimeric PSI complexes immobilized onto $\pi$ system-modified graphene electrodes [34]. Cyanobacterial PSI on glassy carbon electrodes (GCE) modified with multiwalled carbon nanotubes (MWCNTs) using carboxylated pyrene derivative achieved covalent fixation of PSI [35]. There is a strong interaction between conjugated aromatic compounds, such as graphene, due to $\pi$ - $\pi$-stacking capabilities to adsorb PSI onto a graphene-modified surface via electrostatic interactions [34]. A pyrene-based graphene-PSI biohybrid system produced high photocurrent outputs up to $23-135 \mu \mathrm{A} \mathrm{cm}^{-2}$ [34].

Different polycyclic aromatic compounds can act as an interface between PSI and graphene-based semiconductors while supporting the electrochemical communication of the biomolecule with the electrode [36]. A PSI-polyaniline composite film best performed when deposited to a film thickness of $185 \mathrm{~nm}$, yielding an over 200-fold improvement in photocurrent output over a traditionally deposited PSI multilayer film of similar thickness [32]. pH-dependent poly(vinyl)imidazole osmium bis(2,2'-bipyridine) chloride redox polymer has also been utilized to improve electronic contact with PSI, yielding an electron transfer rate of up to $335 \pm 14 \mathrm{e}^{-} \mathrm{s}^{-1} \mathrm{PS}^{-1}$ [1]. A completely organic, optically transparent electrode can be constructed by using reduced graphene oxide (RGO) on which a functional plant PSI multilayer can be deposited [37].

In 2012, the integration of PSI films with p-doped silicon resulted in the highest reported photocurrent enhancement for a PSI biohybrid electrode [38]. Performing confined-plume-chemical deposition (CPCD) enabled the construction of a semiconductor-biological interface for solar energy conversion that optimizes biological and other temperature-sensitive substrates [39]. Depositing a crystalline material zinc oxide ( $\mathrm{ZnO}$ ) anode on PSI-p-doped silicon films via CPCD helped prevent damage to the PSI biomaterial and the need for seeding crystals [39]. Another way to maintain stable, electrochemically active PSI is to encapsulate it in a conductive polymer, such as Nafion, which acts as a support matrix for PSI electrodes [7]. Optimal effectiveness and efficiency are found in biohybrid solar cells that consisted of PSI/Nafion films, specific mediators and polymers, a $10 \mu \mathrm{g} \mathrm{cm}^{-2}$ surface density, and a $100 \mu \mathrm{g} \mathrm{cm}^{-2}$ photoactive protein loading surface density [7].

\subsubsection{Electrode Materials and Modifications}

The modification of a surface to improve biocompatiblity and constructive interactions at the biological-inorganic interface is necessary to establish good contact between the material and reaction center, which allows for electron transfer or interaction. The surface interactions and adsorption 
of PSI onto electrodes or semiconductors could include self-assembled monolayers (SAMs), as well as molecular tethers or peptide segments containing carboxylic acid anchoring groups, alcohols, and thiols.

A novel biomimetic approach for an effective assembly of PSI with the electron transfer carrier cytochrome $c_{6}$ (cyt c) deposited on a thiol modified gold surface was reported in 2014 [40]. Cyt $c_{6}$ acts as the in vivo reducer of PSI in cyanobacterial photosynthesis. This approach involved using cyt $\mathrm{c}$ as a template for the assembly of an oriented, densely packed PSI layer as well as a wiring agent to direct electrons from the electrode towards PSI [40]. An intermittent cyt c layer was necessary in this study for an efficient connection of PSI layers with the electrode, as well as for enhanced photocurrent density [40]. Further work on cytochromes yielded five distinct bioengineered hexahistidine (His6)-tagged cyt $\mathrm{c}_{6}$ variants by introducing the specific linker peptides of 0-19 amino acids (AA) in length between the cyt $c_{6}$ holoprotein and a C-terminal His6-tag affinity tag used for specific immobilization on the semiconductor surface [41]. This yielded a significantly higher number of feasible conformations of immobilized cyt c variants when longer, more flexible linker peptides were utilized. Tagged cyt $\mathrm{c}_{6}$ was able to biopassivate the semiconductor substrate, giving these biohybrid photoelectrochemical cells some characteristics of the p-n-type diodes, although varying dark saturation current level (J0) considered as the charge recombination parameter [41].

PSI has been immobilized on nanoporous gold leaf (NPGL) electrode surfaces to give a light intensity-dependent photoinduced electric current [42]. Gold is a commonly utilized electrode material in biohybrid electrodes and devices due to its high conductivity and biologically inert nature. Au can be functionalized for covalent protein binding with 3-mercapto-1-propane-sulfonate and 2,2'-dimethyl-4,4'-bipyridine to form a self-assembled monolayer (SAM) [43]. A uniform PSI monolayer assembled on C9 alkanethiolate SAM/Au surfaces has increased photocurrent density with increasing dissolved oxygen concentrations, potentially from oxygen helping to drive forward electron transfer from PSI by acting as an electron acceptor [4]. The PSI-mediated electron transfer for an analogous 2D system can be improved through dealloying, which would sufficiently enlarge the pores on the electrode surface [42]. Another cross linker, 2-iminothiolane (2IT), is capable of connecting protein molecules with covalent bonds to metal surfaces. 2IT was used to stabilize PSI multilayer films on gold substrates against significant desorption and degradation upon addition of the liquid electrolyte solution and upon performing photoelectrochemical activity, with superior thickness retainment of the cross-linked PSI films compared to non-cross-linked films [44].

A biohybrid photoanode of PSII extracted from fresh spinach entrapped on mesoporous tungsten oxide $\left(\mathrm{WO}_{3}\right)$ film can be fabricated on fluorine-doped tin oxide. This architecture communicates with the $\mathrm{WO}_{3}$ electrode in the absence of any soluble redox mediators and sacrificial reagents under the visible light of the solar spectrum up to $700 \mathrm{~nm}$ [45].

\subsection{Redox Mediators}

Beyond electrode materials and architectures, the performance of biohybrid devices can be improved with redox mediators, which assist in both directing electrons to the biological photosensitizer and in enhancing conductivity between the electrodes. Upon photo-oxidation, it is necessary for the photosensitizer (such as PSI) to be reduced for another photo-oxidation event to occur. Mediators with suitable redox potentials for accepting electrons are an essential component to the conversion of light to energy. However, not all redox mediators are suitable for biohybrid photoelectrochemical devices. The traditional DSSC I${ }^{-} / \mathrm{I}_{3}{ }^{-}$redox mediator is corrosive to both protein and metal, has a midpoint potential similar to PSI, and intensely absorbs light in the visible spectrum [46]. Generation of reactive oxygen species in devices operated under aerobic operation compromises the long-term stability of photosynthetic biophotoelectrodes, even though molecular oxygen can help decrease PSI charge recombination rates [47]. Under anaerobic conditions, the operation of a PSI-based photocathode using an electron acceptor that enables photocurrent generation can substantially improve stability and allow for exposure to higher light intensities [47]. 
Further, the transfer of electrons to and from reaction centers is much slower than the primary charge separation events of these photosensitizers, and the ability and rate of electron donation/acceptance of mediators with photosensitizers plays a key role in biohybrid device performance at the solution-electrode interface as governed by Butler-Volmer kinetics [48]. Publications on research involving redox mediators include small organic-based molecules, such as methyl viologen (MV), 2,6-dichlorophenolindophenol (DCPIP), and ferricyanide complexes. Organometallic redox mediators include cobalt-, ruthenium-, and osmium-based complexes typically coordinated by bipyridine ligands. Solid-state electrons can be shuttled and be donated to a secondary acceptor via organic polycationic polymers, such as polyviologens [15]. There are multiple studies utilizing the biological PSI electron donor cyt $c_{6}$ as well. However, this is one of the least-studied areas of biohybrid photoelectrochemical electrodes and devices, and is likely an area where significant improvements in performance could be made.

One commonly used class of molecules as diffusible sacrificial electron mediators in PSI-based systems are MV [15]. MV can also be used as a charge carrier for the collection of electrons at the reduced $F_{B}$ PSI site, as it can act as an acceptor of electrons from PSI [49]. Photoexcited PSI has also been shown to interact with polyviologens in solid-state devices. PSI-polyviologen protein surfaces immobilized in Nafion polymer have been shown to significantly enhance photocurrent, aid in electron transfer, stabilize PSI through immobilization, and enhancing electrolyte conductivity [15]. Lower Nafion concentrations have been shown to increase redox mediator diffusivity with both $\mathrm{Os}(\mathrm{bpy})_{2} \mathrm{Cl}_{2}$ and MV redox mediators [7]. As another alternative redox mediator, cobalt complexes can be used in PSI biohybrid solar cells because they are not corrosive and they offer more negative redox potentials to drive the reduction of PSI [46].

PSI integrated within a redox hydrogel polymer acts as a conducting matrix for the transfer of electrons from electrode surfaces to the photo-oxidized PSI [49]. Oxygen drives MV to initiate a light-induced unidirectional electron transfer, which results in photocurrent from an electron donor Au surface via surface assembled PSI trimers. PSI wet cells typically use MV and either ferrocyanide mediators or osmium-based mediators. In PSI/SAM/Au systems, dissolved oxygen in solution forms a complex intermediate species with MV to mediate redox pathways [4].

Developments with devices involving PSI-based light conversion to electrical energy have increased the knowledge of materials and methods that optimize the photocurrents and photovoltages generated. We have systematically analyzed research articles concerning PSI-based biohybrid devices published within the past decade. Tables 1 and 2 briefly summarize some of the key characteristics of plant and cyanobacterial PSI-based biohybrid solar cells that include a value for photocurrent and have been recently investigated.

Table 1. Photocurrent Analysis of Higher Plant PSI-Based Biohybrid Devices ${ }^{\dagger}$.

\begin{tabular}{|c|c|c|c|c|}
\hline Electrode Surface/Immobilization & Redox Mediators & Photocurrent $\left(\mu \mathrm{A} \mathrm{cm}^{-2}\right)$ & $\begin{array}{l}\text { Current Density } \\
\left(\mu \mathrm{A} \mathrm{cm}-2 \mathrm{~mW}^{-1}\right)\end{array}$ & Ref. \\
\hline $\begin{array}{c}\text { Terephthalic-dialdehyde SAM on } \\
\text { nanoporous gold }\end{array}$ & $\begin{array}{c}\text { Sodium ascorbate; } \\
\text { 2,6-dichloroindophenol }\end{array}$ & 0.3 & 0.08 & [42] \\
\hline Bare gold & $\begin{array}{c}\text { Sodium ascorbate; } \\
\text { 2,6-dichlorophenolindophenol }\end{array}$ & N/A & 0.1 & [50] \\
\hline PSI-based biohybrid cells & $\begin{array}{c}\text { Sodium ascorbate; } \\
\text { 2,6-dichloroindophenol }\end{array}$ & 2 & 0.138 & [51] \\
\hline PSI films/p-doped silicon & Methyl viologen & 875 & 4.6 & [38] \\
\hline PSI multilayer/reduced graphene oxide & $\begin{array}{l}\text { Ferrocyanide; methylene blue; } \\
\text { sodium ascorbate; methyl } \\
\text { viologen; } \\
\text { 2,6-dichlorophenolindophenol; } \\
\text { ruthenium(II) hexamine }\end{array}$ & 1.2 & N/A & [37] \\
\hline PSI multilayer film on gold & Ferricyanide & 0.9 & N/A & [5] \\
\hline Polyaniline-PSI film on gold surface & Sodium ascorbate & 5.7 & N/A & [32] \\
\hline
\end{tabular}


Table 1. Cont.

\begin{tabular}{|c|c|c|c|c|}
\hline Electrode Surface/Immobilization & Redox Mediators & Photocurrent $\left(\mu \mathrm{A} \mathrm{cm}^{-2}\right)$ & $\begin{array}{l}\text { Current Density } \\
\left(\mu \mathrm{A} \mathrm{cm}^{-2} \mathrm{~mW}^{-1}\right)\end{array}$ & Ref. \\
\hline PSI-polyaniline/titanium dioxide & Methyl viologen & 72 & N/A & [52] \\
\hline $\begin{array}{l}\text { Solid-state unetched p-doped } \\
\text { silicon/PSI }\end{array}$ & Methyl viologen & $\begin{array}{l}\text { Non-etched: } 21 \text { Etched: } \\
127\end{array}$ & N/A & [39] \\
\hline $\begin{array}{l}\text { PSI multilayer film/SAM on gold-coated } \\
\text { silicon }\end{array}$ & $\begin{array}{l}\text { Osmium-based redox } \\
\text { hydrogel }\end{array}$ & $\begin{array}{l}\text { 2-iminothiolane-cross-linked: } \\
\qquad 8\end{array}$ & N/A & {$[44]^{\mathrm{a}}$} \\
\hline $\begin{array}{l}\text { PSI-poly(3,4-ethylene-dioxythiophene): } \\
\text { poly-styrenesulfonate/fluorine-doped } \\
\text { tin oxide }\end{array}$ & N/A & 960 & N/A & [2] \\
\hline $\begin{array}{c}\text { PSI multilayer } \\
\text { film/gold/SAM/aminoethanethiol }\end{array}$ & {$[\mathrm{Fe}(\mathrm{CN}) 6]^{4-} ;[\mathrm{Fe}(\mathrm{CN}) 6]^{3-}$} & $\begin{array}{l}0-0.84 \text { for PSI film } \\
\text { thickness } 0-1.3 \mu \mathrm{m}\end{array}$ & $\mathrm{N} / \mathrm{A}$ & [48] \\
\hline PSI-p-doped silicon & Methyl viologen; polyviologen & $\mathrm{N} / \mathrm{A}$ & N/A & [15] \\
\hline
\end{tabular}

Table 2. Photocurrent Analysis of Cyanobacterial PSI-Based Biohybrid Devices $\ddagger$.

\begin{tabular}{|c|c|c|c|c|c|}
\hline PSI Source & $\begin{array}{c}\text { Electrode } \\
\text { Surface/Immobilization }\end{array}$ & Redox Mediators & $\begin{array}{l}\text { Photocurrent } \\
\left(\mu \mathrm{A} \mathrm{cm}^{-2}\right)\end{array}$ & $\begin{array}{l}\text { Current Density } \\
\left(\mu \mathrm{A} \mathrm{cm}-2 \mathrm{~mW}^{-1}\right)\end{array}$ & Ref. \\
\hline T. elongatus & PSI/SAM on gold surface & Sodium ascorbate & 0.088 & $\mathrm{~N} / \mathrm{A}$ & {$[43]^{a}$} \\
\hline T. elongatus & PSI/thiol-modified gold & $\begin{array}{l}\text { Ascorbate-reduced } \\
\text { 2,6-dichloroindophenol; } \\
\text { methyl viologen }\end{array}$ & 1 & 0.97 & {$[40]^{\mathrm{a}}$} \\
\hline T. elongatus & $\begin{array}{l}\text { PSI/pi system-modified } \\
\text { graphene }\end{array}$ & Methyl viologen & 135 & $\mathrm{~N} / \mathrm{A}$ & {$[34]^{b}$} \\
\hline T. elongatus & $\begin{array}{c}\text { ZOBiP-PSI- or } \\
\text { TOBiP-Fd-PSI-based } \\
\text { biohybrid dye-sensitized } \\
\text { solar cells }\end{array}$ & Cyt $c_{6}$ & N/A & N/A & {$[30]^{a}$} \\
\hline T. elongatus & $\begin{array}{c}\text { PSI/transparent } \\
\text { mesoporous indium tin } \\
\text { oxide }\end{array}$ & N/A & 150 & N/A & [54] \\
\hline T. elongatus & $\begin{array}{c}\text { PSI on } \mathrm{C}_{9} \text { alkanethiolate } \\
\mathrm{SAM} / \mathrm{Au}\end{array}$ & Methyl viologen & 0.006 & N/A & {$[4]$} \\
\hline
\end{tabular}

$\ddagger$ PSI-based biohybrid solar cell component information with its respective generated photocurrent. PSI source came from the cyanobacteria Thermosynechococcus elongatus (orange) and Rhodobacter sphaeroides (blue). The HT3 cells are from genetically PSII-modified Synechocystis sp. PCC 6803 strain. Electron donors and acceptors are indicated under the redox mediators category. The photocurrents are reported in $\mu \mathrm{A} \mathrm{cm}^{-2}$. Any unavailable, multiple, or estimated data is indicated with (N/A). ${ }^{a}$ Reference was conducted to improve the photocurrent performance of PSI-based biohybrid cells. ${ }^{b}$ Reference reported other estimated photocurrent values observed in different conditions or solar cell composition. 


\subsection{Biofilms, Microbial Solar Cells, and Thylakoid Membrane-Based Solar Cells}

In this section, we will continue to look at other types of photocurrent-producing cells, focusing specifically on biofilms, microbial, and thylakoid membrane-based solar cells. Another type of bioelectrochemical system that generates an observable electric current is microbial fuel cells, which can capture the produced electrons in the chemical reactions. Electrical photocurrents can occur in biofilms through electron transfer across active photosynthetic bacterial membranes [57]. There is a greater prevalence of a redox shuttle mechanism than a direct conduction mechanism in the electron transfer from the bacteria to the electrode. The limitations of this mechanism for devices harvesting solar energy is the charge transferred to the electrode [57].

Bioelectrochemical photocurrent harvesting and photo response rate are enhanced using ternary indium tin oxide (ITO) electrodes with porosities lengths between nanometers and micrometers [58]. Researchers have also demonstrated how to generate the highest electrical power output with a non-sulfur purple bacterium, such as R. sphaeroides [55]. A current density of $405.63 \mathrm{~mA} \mathrm{~m}^{-2}$ can be obtained by using $R$. sphaeroides in the anodic part of a microbial fuel cell, permanganate as the cathodic electrolyte, the platinum as the anodic electrode, the graphite as the cathodic electrode, and a $2.1 \mathrm{~cm}^{2}$ cathodic surface [55].

The difference between biophotovoltaic systems (BPVs) and microbial fuel cells is that the former generates an extracellular electrical current through oxygenic photosynthetic microorganisms upon illumination. BPVs can provide a power density of $0.5 \mathrm{~W} \mathrm{~m}^{-2}$, which is enough to power small electrical devices. Progress has been made in the development of BPVs in terms of methods to improve efficacy and the utilization of optimal biological materials, electrodes, and interfacial wiring [58].

The intact thylakoid membranes can be used in a photoelectrochemical cell to capture light. The membrane can be adsorbed without a linker by using an aerosol technique and electrohydrodynamic atomization [59]. Under these conditions and upon UV and visible light illumination, the maximum photocurrent density was $6.7 \mathrm{~mA} \mathrm{~cm}{ }^{-2}$, while a photocurrent density of $12 \mu \mathrm{A} \mathrm{cm}{ }^{-2}$ was generated upon visible light illumination [59]. A novel single-junction organic solar cell stack composed of spinach PSI, tyrosine, ITO, C60, and Au would yield a current density of $3470 \mu \mathrm{A} \mathrm{cm}^{-2}$ [60].

\section{Hydrogen Evolution Photocatalyzed by Biological Reaction Centers}

\subsection{Early History of Photosynthetic Hydrogen Production}

It has been known for nearly 80 years that green algae are capable of converting light energy into molecular hydrogen. This observation was initially reported by Hans Gaffron in 1939 [61]. Gaffron was later able to demonstrate, using inhibitors of the flow of electrons during the light reactions of photosynthesis, that algae were able to catalyze the photoproduction of $\mathrm{H}_{2}$ via non-cyclic electron flow through Photosystem I (PSI) to a hydrogenase enzyme [62]. Further, it was shown $[63,64]$ that these algae are capable of simultaneously producing oxygen and hydrogen, with a ratio of $\mathrm{H}_{2}$ to $\mathrm{O}_{2}$ at 1.9, approaching the theoretical ratio of 2.0 [63]. The ability of these algae to produce hydrogen was found to be linked to their ability to express a hydrogenase [65-67] that is capable of accepting electrons donated by PSI. These algal hydrogenases are representative of the class of [FeFe]-type hydrogenases that are linked to the photosynthetic electron transport chain [68]. Although it is accepted that the plastids present in higher plants arose from cyanobacteria, genomic analysis indicates that cyanobacteria contain only [NiFe] hydrogenases, and appear to lack the [FeFe]-type hydrogenases that are found in green algae $[69,70]$. While these two hydrogenase classes catalyze the same chemical reaction in the end, [NiFe] types are approximately 3-fold more abundant and tend to be more $\mathrm{O}_{2}$ tolerant as compared to [FeFe]-type hydrogenases [71]. Recent studies have suggested the possibility of an in vitro method for stably and reversibly reversing $\mathrm{O}_{2}$ inactivation of an [FeFe] hydrogenase from the non-photosynthetic organism Clostridium beijerinckii ( $\mathrm{CbA5H}$ ), which may be able to be used with other [FeFe] hydrogenases as well [72]. In vitro strategies for hydrogen production utilizing purified 
biological reaction centers have historically utilized either coupling with a hydrogenase enzyme or platinization of the reaction center, as shown in Figure 4 below.
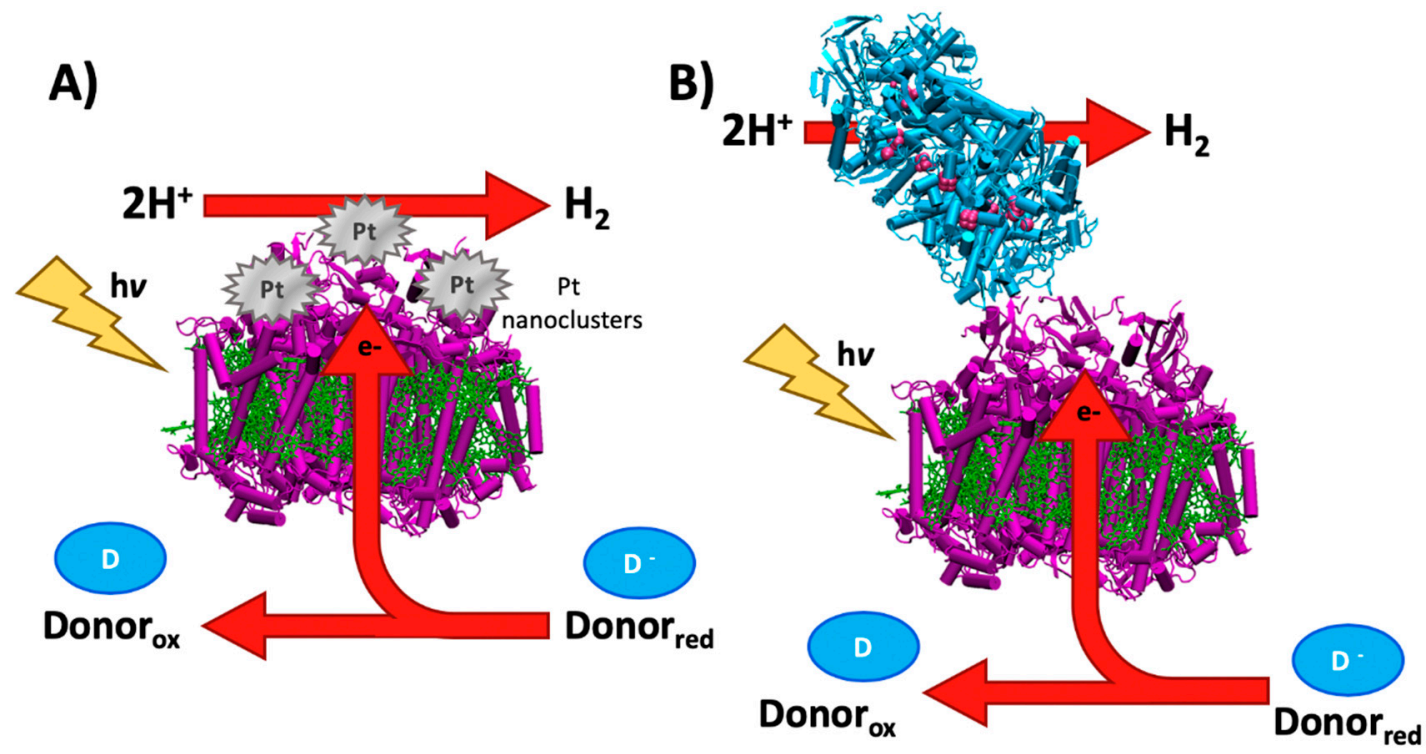

Figure 4. Comparison of methods for hydrogen evolution by reaction centers. Two common methods for reaction center modification for hydrogen evolution are platinization, shown in (A), and coupling to a hydrogenase enzyme, shown in (B). Shown in purple in both panels is the protein backbone of PSI, with chlorophyll antenna shown in green. A [Fe-Fe] hydrogenase enzyme is shown in 4B in light blue, with metal clusters shown in pink. The flow of electrons from the donor molecule through the reaction center are shown in red arrows. Figure adapted from [73].

\subsection{Bioengineered In Vivo Hydrogen Production}

Recently, there has been considerable interest in using bio-inspired methods to produce hydrogen, as current methods of $\mathrm{H}_{2}$ fuel production still utilize natural gas, electricity, and conventional $\mathrm{CO}_{2}$-emitting power plants [74]. In principle, the utilization of either whole photosynthetic organisms or purified biological enzymes is of interest as they can employ the highly efficient process of photosynthesis to produce $\mathrm{H}_{2}$ from two simple and abundant yet renewable resources, sunlight and water. Previous work has identified two independent pathways of $\mathrm{H}_{2}$ production catalyzed by photosynthetic organisms that could potentially be utilized for energy production. Greenbaum and co-workers demonstrated the existence of a low-level but continuous electron transport pathway based on oxygenic photosynthesis [75-77]. This is distinct from a second, fermentative, pathway of electron transport for $\mathrm{H}_{2}$ production reported by Gaffron, Gibbs, and co-workers [62,65,78-80]. However, it is now clear that both of these electron-transport processes have limitations in both sustainability and yield. Photosynthetic $\mathrm{H}_{2}$ production with $\mathrm{H}_{2} \mathrm{O}$ as the source of electrons cannot be sustained beyond a few minutes because $\mathrm{O}_{2}$, derived from the water splitting activity of Photosystem II (PSII), functions to both inactivate the hydrogenase enzyme as well as a negative regulator of hydrogenase expression [70]. On the other hand, hydrogen evolution derived from the catabolism of endogenous substrates in green algae does not have the reservoir capacity to sustain high rates of electron transfer to the photosynthetic apparatus necessary for scaled-up $\mathrm{H}_{2}$ production.

Although the incompatibility of simultaneous photocatalytic production of $\mathrm{O}_{2}$ and $\mathrm{H}_{2}$ remained problematic for many years [81], a simple and elegant solution was reported in the late 1990s [82]. By using a nutrient-induced two-stage growth cycle for photosynthetic organisms, the processes of oxygen evolution and hydrogen production may be separated temporally and is capable of being sustained for hours. Using replete substrate-rich media in stage 1, normal oxygenic photosynthesis occurs, and the algae are deprived of sulfur-containing nutrients in stage 2 . This makes the organisms unable to 
repair PSII, thus attenuating oxygen evolution as water splitting is not occurring to evolve $\mathrm{O}_{2}$. This alters the normal pathways of electron transport in photosynthesis; electrons are now derived from substrate donation directly into photosynthetic electron transport without PSII via one or more catabolic processes instead of via water splitting. These electrons are then in turn provided to a hydrogenase via PSI yielding hydrogen. This system has been shown to work in the algae Chlamydomonas reinhardtii and has been studied in some detail [83]. Chlamydomonas reinhardtii has also shown the ability to utilize chlororespiration catalyzed by PSI and flavodiiron proteins to drastically increase its $\mathrm{O}_{2}$ uptake rate under high light conditions [84]. This has been found to generate microoxic niches within the thylakoids of Chlamydomonas, allowing for microenvironments where its $[\mathrm{FeFe}]$ hydrogenases $\left(\mathrm{H}_{2}\right.$-ases $)$ are protected from oxidation by molecular $\mathrm{O}_{2}$, but to also improve hydrogenase catalytic activity even significantly under aerobic culture conditions. Recently, live cyanobacterial cultures have been incorporated into biohybrid devices and have been shown to generate a biophotoelectrochemical system capable of producing stable photocurrent and molecular $\mathrm{H}_{2}$ [85].

\subsection{Overcoming Kinetic Limitations of Hydrogen Evolution}

As described above, it has been shown in vivo that the cyanobacteria and eukaryotic algae and plants utilize the photosynthetic reactions in their thylakoid membranes to divert electrons from PSI under anaerobic conditions towards $\mathrm{H}_{2}$-producing $\mathrm{H}_{2}$-ases. Unfortunately, it has been shown that in many organisms, the $[\mathrm{FeFe}] \mathrm{H}_{2}$-ases are irreversibly inhibited by $\mathrm{O}_{2}$, which makes this conversion short lived and greatly limits the industrial or economic feasibility of $\mathrm{H}_{2}$ by these [FeFe] $\mathrm{H}_{2}$-ases [86]. Moreover, to efficiently couple electron transfer from the water splitting complex in PSII through PSI to the $\mathrm{H}_{2}$-ase, there are three diffusion-limited steps: PQ diffusion from PSII; plastocyanin (PC)/cyt $\mathrm{c}_{6}$ diffusion from the cyt $\mathrm{b}_{6} / \mathrm{f}$ complex to PSI; and reduced ferredoxin diffusion from PSI to $\mathrm{H}_{2}$-ase. All of these processes represent rate-limited steps and impose kinetic limits on the overall synthesis.

Early work showed that this diffusion limitation could be overcome in vitro by covalently coupling the electron donor PC to spinach PSI via a chemical cross linker. Following cross linking, it was observed that the yield of hydrogen production from platinum nanoparticles could be increased $>300 \%$ [87]. Interestingly, by using bioengineering to directly attach the distal [4Fe-4S] cluster of the $[\mathrm{FeFe}] \mathrm{H}_{2}$-ase from Clostridium acetobutylicum to the terminal $[4 \mathrm{Fe}-4 \mathrm{~S}]$ cluster of $\mathrm{F}_{\mathrm{B}}$ on the acceptor side of PSI, a $>2 \times$ increased yield in electron flow compared to the in vivo oxygenic photosynthesis process was seen. By building this biological/organic biohybrid, the work further demonstrated the feasibility of using synthetic biology methods to tether together and even redesign redox components to overcome diffusion-based rate limitations on electron transfer reactions [88]. More recently, it was observed that some of these diffusion-limited reactions could be influenced in vivo by genetic manipulation of the grana diameter in the thylakoid membrane ultrastructure [89]. This work clearly demonstrated that plastocyanin diffusion to PSI becomes much slower if the grana diameter exceeds $\sim 500 \mathrm{~nm}$. This work is consistent with prior Brownian diffusion modeling work that indicates that PC diffusion limits electron transport in linear electron transport (LET) where it was observed, that increasing the grana diameter causes a 14-fold reduction in PC diffusion time between the cyt $b_{6} / f$ complexes and PSI [90]. These two reports would suggest that if bioengineering could engineer and significantly restrict the grana diameter that it may be possible to enhance one of these rate limiting steps to allow fast and efficient LET in higher plants and possible observe enhanced $\mathrm{H}_{2}$ output from cultivated cyanobacteria or algae in bioreactors.

Coupling of these early results suggest that the direct fusion of hydrogenase mutants with PSI via the stromal subunits could provide a much higher rate of in vivo hydrogen production. The feasibility of these PsaD/E hydrogenase fusions has already been shown in cyanobacteria where an artificial fusion protein composed of the membrane-bound [NiFe] hydrogenase from the Ralstonia eutropha $\mathrm{H} 16$ fused in vivo to the peripheral PSI subunit PsaE of the cyanobacterium Thermosynechococcus elongatus to yield hydrogen production [91]. Following a similar strategy, it was recently reported that the NiFe hydrogenase (HoxYH) of the cyanobacterium Synechocystis sp. PCC 6803 could be directly fused to 
the stromal-exposed PsaD subunit in PSI. This would allow electrons that would normally go from [4Fe4S] cluster of FB in PSI directly to a soluble ferredoxin carrier to be directly transferred to the NiFe hydrogenase. This psaD-hoxYH cyanobacterial mutant was shown to still fix carbon and able will grow photoautotrophically while also yielding $500 \mu \mathrm{M} \mathrm{H}_{2}$ under anaerobic conditions in the light [92]. With a similar approach in Chlamydomonas it was also shown that by making a ferredoxin-HydA fusion gene, the bipartite fusion protein was is able to accept photosynthetic electrons from PSI and use them for efficient hydrogen production [93]. They observed that Fd-HydA construct has a $~ 4.5$-fold greater photosynthetic $\mathrm{H}_{2}$ yield than the native WT HydA in vivo. This work has been extended to bring the hydrogenase even closer to PSI by insertion of the HydA sequence into the PsaC subunit. This synthetic construct promoted the self-assembly of the PSI and hydrogenase portions to yield an active in vivo ensemble. Interestingly, the algal cells expressing this PSI-hydrogenase chimera continued to make $\mathrm{H}_{2}$ in a light-dependent fashion for several days [94].

\subsection{In Vitro Strategies for Hydrogen Evolution}

However, as mentioned, this extracted PSI must then be either functionalized or linked to a $\mathrm{H}_{2}$-producing catalyst, either synthetic or biological [95]. An alternative approach to in vivo photosynthetic hydrogen production that has been proposed employs biochemically-isolated PSI reaction centers. The same kinetic and structural properties, which are unsurpassed by synthetic systems for electronic current production, similarly make PSI an ideal candidate for inclusion in biohybrid $\mathrm{H}_{2}$ producing devices. In PSI, photon absorption initiates a unidirectional electron transfer sequence that generates a reducing electron over a distance of $6 \mathrm{~nm}$ [96], a reaction that is completed within $150 \mathrm{~ns}$ [97]. This photocatalysis is highly efficient, with a quantum yield close to $100 \%[98,99]$. By coupling the low-potential electron-emergent end of PSI complexes ( $-0.6 \mathrm{~V}$ versus SHE) to either platinum nanoparticles [87,100] or covalently linked hydrogenase [91,101], the photochemically produced electrons can catalyze the reduction of protons to hydrogen in vitro.

The most commonly studied type of functionalization is the platinization of PSI with Pt nanoparticles, first published in 1985 by Greenbaum [102], and has been found to be remarkably stable with over 85 days of photocatalysis reported [73]. In these cases, the Pt was directly deposited onto the surfaces of the photosynthetic catalysts, but other more recent studies found improvements in $\mathrm{H}_{2}$ production when $\mathrm{Pt}$ nanoparticles were tethered using a molecular wire, giving spatial separation between PSI electron generation and Pt-catalyzed $\mathrm{H}_{2}$ production [103]. This has been further corroborated by molecular dynamics studies on PSI/[FeFe] hydrogenase enzyme hybrid systems that studied the effect of molecular wire length between the two enzymes on the stability of the system. This system has the potential of utilizing solar energy twice: (1) first, light will be used to grow the photosynthetic organism that will express and assemble the very complex biomolecular hydrogen evolving machinery; (2) once extracted and functionalized, solar energy will be used to drive photosynthetic electron transport in PSI a second time to produce hydrogen in vitro.

There are many potential methods being studied for the improvement of these biohybrid $\mathrm{H}_{2}$-producing systems. As these systems tend to be sensitive to oxygen, there is interest in developing either anaerobic cells or in potentially the incorporation of oxygen and superoxide scrubbers to help improve $\mathrm{H}_{2}$ yields. One study utilizing platinized PSI and an osmium-based conductive polymer semiconductor for wiring the PSI protein to the electrode found good production of photocurrent through the device, though actual $\mathrm{H}_{2}$ production was not quantified [104]. Further, while the quantum efficiency of PSI's photoinduced electron generation approaches $100 \%$, a report by Applegate found a quantum yield of $10-15 \%$ when photoexcitation energy between $400-700 \mathrm{~nm}$ was assessed [105]. In attempts to improve this quantum yield, Nagakawa et al. utilized the addition of an artificial light-harvesting dye, Lumogen Red, to improve the wavelengths of light available for PSI photocatalytic activity and saw large improvements over the non-dye modified PSI-Pt constructs [13]. Utilizing a different strategy to improve $\mathrm{H}_{2}$ yields by reducing the light-harvesting chlorophyll pigments 
in Chlamydomonas reinhardtii 5-6-fold yielded approximately 2-5-fold increases in $\mathrm{H}_{2}$ production depending on the exact mutant strain studied [106].

\subsection{Emerging Technologies for Bioengineering Hydrogen Evolution}

The fact that PSI has been shown active in both the solid state [107] and in solution for over 280 days [51] suggests that we may be able to produce a highly stable, cell-free hydrogen-evolving system that may prove to be a feasible, solar-driven energy solution [108]. Furthermore, future improvements may allow direct electron extraction from water using a coupled PSII to PSI system capable of recapitulating the photosynthetic electron transport chain in a new hybrid nanoparticle similar to what has been done in solution [109] suggests that fully synthetic, biohybrid solar-to-fuel ensembles may be possible. The ability to use solar energy to split water with only $\mathrm{H}_{2}$ and $\mathrm{O}_{2}$ as the products is an ideal, carbon-neutral energy goal with considerable promise. One challenge to such a device is to somehow protect the hydrogenases that are sensitive to $\mathrm{O}_{2}$ by some sort of sequestration similar to how a similarly $\mathrm{O}_{2}$ sensitive enzyme, nitrogenases, are separated from $\mathrm{PSII} \mathrm{O}_{2}$ evolution in heterocysts [110,111].

It may be possible to use synthetic biology and nanofabrication to create an immobilization platform that sequesters the hydrogen production chemistry (PSI and catalyst) from the water splitting chemistry (PSII). In this way the $\mathrm{O}_{2}$ sensitive catalyst, such as the $\mathrm{H}_{2}$-ase or other catalyst, can be separated from oxygen production by a water-splitting system (PSII or synthetic). One such configuration is shown in Figure 5, where the use of a self-assembled 2D array of PSI and PSII can be supported using some synthetic polymer matrix that replaces a lipid bilayer (Figure 5E). Recently, there has been progress in isolating photosynthetic reaction centers $[112,113]$ and other electron transport complexes [114] without detergents using styrene maleic acid copolymers. These polymers surround not only the membrane protein(s) but also a significant boundary layer that may stabilize the protein in a more native confirmation. As a synthetic polymer, these SMAs are very amenable to chemical functionalization that may permit cross linking within the lateral bilayer region [115]. Relevant to this goal, these SMALP proteins have been shown to be more stable [116,117] and in the case of PSI have even been shown to undergo more rapid photochemistry [118]. These layers can be assembled into a multilaminar array with a conductive nanowire connecting PSII to PSI. Although cyt $\mathrm{c}_{6}$ is not a normal electron acceptor of PSII, there is over $800 \mathrm{mV}$ of driving force that may enable this alternate path of electron transfer in vitro (Figure 5A). Such a connection has been shown using soluble electron transfer proteins such as cyt $\mathrm{c}_{6}$ to ferry electrons between PSII and PSI (Figure 5B). The diffusion time can be reduced by making a nanowire to bridge this distance. As is shown in Figure 5C, we have already been able to clone and express a multimeric cyt $c_{6}$ polyprotein of five head-to-toe subunits that will assemble correctly in E. coli. MD simulations suggest that each cyt-cyt linkage can extend the heme-heme spacing by $\sim 3.0 \mathrm{~nm}$. The final device structure may involve multiple layers of a polymer-embedded PSII-PSI complex. This design will successfully enable $\mathrm{O}_{2}$ evolution from the splitting of $\mathrm{H}_{2} \mathrm{O}$ in one chamber and the hydrogen evolving catalyst producing $\mathrm{H}_{2}$ in a second chamber (Figure 5E). By physically separating these two chemical conversions, the device will recapitulate the natural design of how cyanobacteria separate these two processes during nitrogen fixation in a heterocyst.

This device illustrates only one possible biohybrid device derived from combining advances in synthetic biology with innovations in material science [3]. Moreover, the ever-expanding genomics and structural biology already known to exist in extremophiles suggest many new possible chemical conversions that may be stable at very high temperatures, pressures, and $\mathrm{pH}$ extremes [119-121]. 

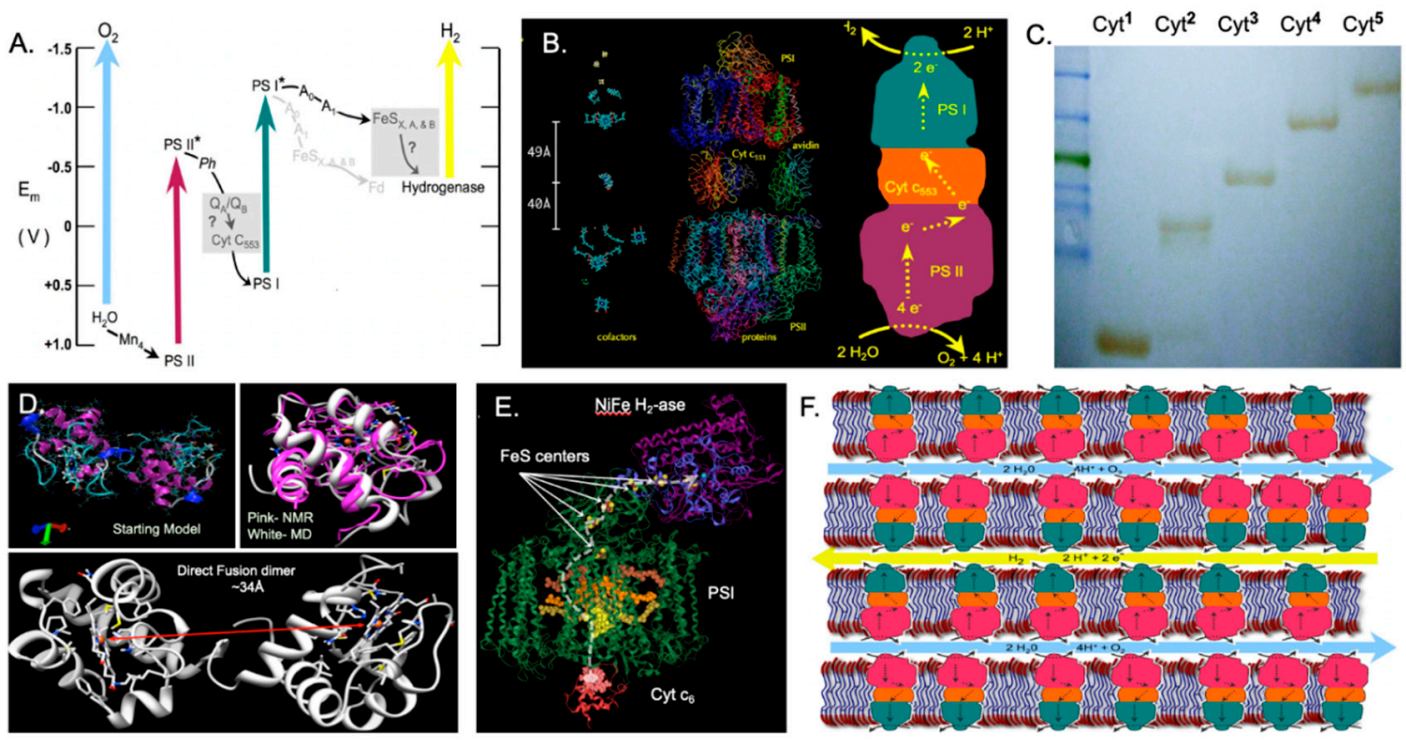

Figure 5. Design of the optimized photosynthetic energy converter (OPEC). (A) Energy level of the two photosystems in the Z-scheme, with changes shown in the two grey boxes: (1) the first box shows the result with the bypassing of the $b_{6} / f$ complex with cyt $c_{6}$ acting as the mobile carrier from PSII to PSI; (2) the second box shows the result of using bioengineering to lower the midpoint potential of the terminal FeS acceptors of PSI $\left(\mathrm{F}_{\mathrm{X}}, \mathrm{A}, \mathrm{B}\right)$ to provide a larger driving force for $\mathrm{H}_{2}$ production via a hydrogenase or catalyst (not shown). (B) An avidin-mediated coupling of PSII to PSI via multiple biotinylation of newly inserted, site-directed Cys mutants on the stromal side of PSII and the lumenal side of PSI is shown. The left panel shows the distances of the cofactors that would result from this cross-linking strategy (all distances are shown to scale). The middle panel shows the protein structures (PSII, cyt.c 6 , 3x-avidin, and PSI) based on published PDB files 1IZL, 1C6S, 2AVI, 1JB0). (C) As is clear from the distance in Panel B, the distance from QB to P700 is $\sim 90 \AA$. To facilitate electron transfer over this long distance, we have designed and expressed a linker-less Cyt c6 polyprotein. These gene fusions are reflected by * and demonstrate the ability to make a penta-cyt $\mathrm{c}_{6}$ polyprotein. (D) Demonstration of a short $90 \mathrm{msec}$ MD simulation of a di-cyt $\mathrm{c}_{6}$ fusion protein: the upper left panel shows the backbone trace of the starting fusion protein; the top right shows the superimposition of cyt $\mathrm{c}_{6}$ monomers based on the starting NMR structure in pink and after the MD simulation; finally, the lower panel shows the Fe-Fe distance $(\sim 20 \AA)$ of the two hemes following this $90 \mathrm{msec}$ simulation. This would suggest that at least a tetra-cyt $c_{6}$ polyprotein would be needed to bridge the PSII-PSI distance shown in (B). (E) Illustration of the direct attachment of a NiFe hydrogenase to the stromal subunit PsaD of PSI with a docked cyt $c_{6}$ on the lumenal surface. The path of electron transfer is shown by the dashed grey arrow and the multiple FeS centers are shown with white arrows. (F) This schematic illustrates how these coupled PSII-cyt $c_{6}-$ PSI complexes could be assembled in a biomimetic polymer that provides a diffusion barrier much like a natural lipid bilayer may function. This complex may be embedded in the amphiphilic polymer (shown in purple) that could be alternated during the assembly process, projecting the oxygen-evolving sides of PSII into one microfluidic zone, analogous to the thylakoid lumen (blue) and the hydrogen evolving surface of PSI would be projected into a second microfluidic cavity analogous to the stroma (yellow).

\section{Biohybrid Photosynthesis with Artificial Reaction Centers}

Biohybrid, or applied photosynthesis entails coupling man-made light-harvesting materials with enzymes for carrying out selected light-driven catalytic processes [122-124]. The work discussed in this section will specifically focus on applied photosynthetic systems that do not rely on PSI or PSII for capturing and converting light energy to chemical or electric potential energy. A common thread with all the work presented throughout this review, however, is that an enzyme is key to achieving overall photocatalysis. This approach takes advantage of nature's ability to do more with less, which is to say 
enzymes combine high chemical selectivity and turnover rates while using abundant elements. This contrasts with the general reliance on scarce or precious elements as with most highly active inorganic catalysts to generate valuable chemical products.

Oxygenic photosynthetic organisms do not directly couple photochemical reactions to terminal catalysis. The processes of light absorption, charge separation, and initial redox catalysis produces $\mathrm{O}_{2}$, protons, and reducing equivalents from water, but the products formed directly by PSII and PSI are not the terminal reduced products formed by the photosynthetic organism. Instead, nature relies on use of specific energy carriers, a small set of reactive chemical species that are generated as a direct result of photosynthesis that then serve as substrates coupled to most all the other enzymatic processes in the organism. These reactive intermediates produced during photosynthesis include plastoquinol, $\mathrm{NAD}(\mathrm{P}) \mathrm{H}, \mathrm{ATP}$, and $\mathrm{O}_{2}$. This presents a straightforward approach to developing biohybrid photosynthetic systems by coupling engineered materials for capturing and converting light to redox equivalents used to generate the reactive intermediate that is then consumed by the enzyme along with the other necessary substrates to achieve the desired catalytic product. In Figure 6, a timeline is shown of products that have been made using the varying photoactivation techniques described further in this section.

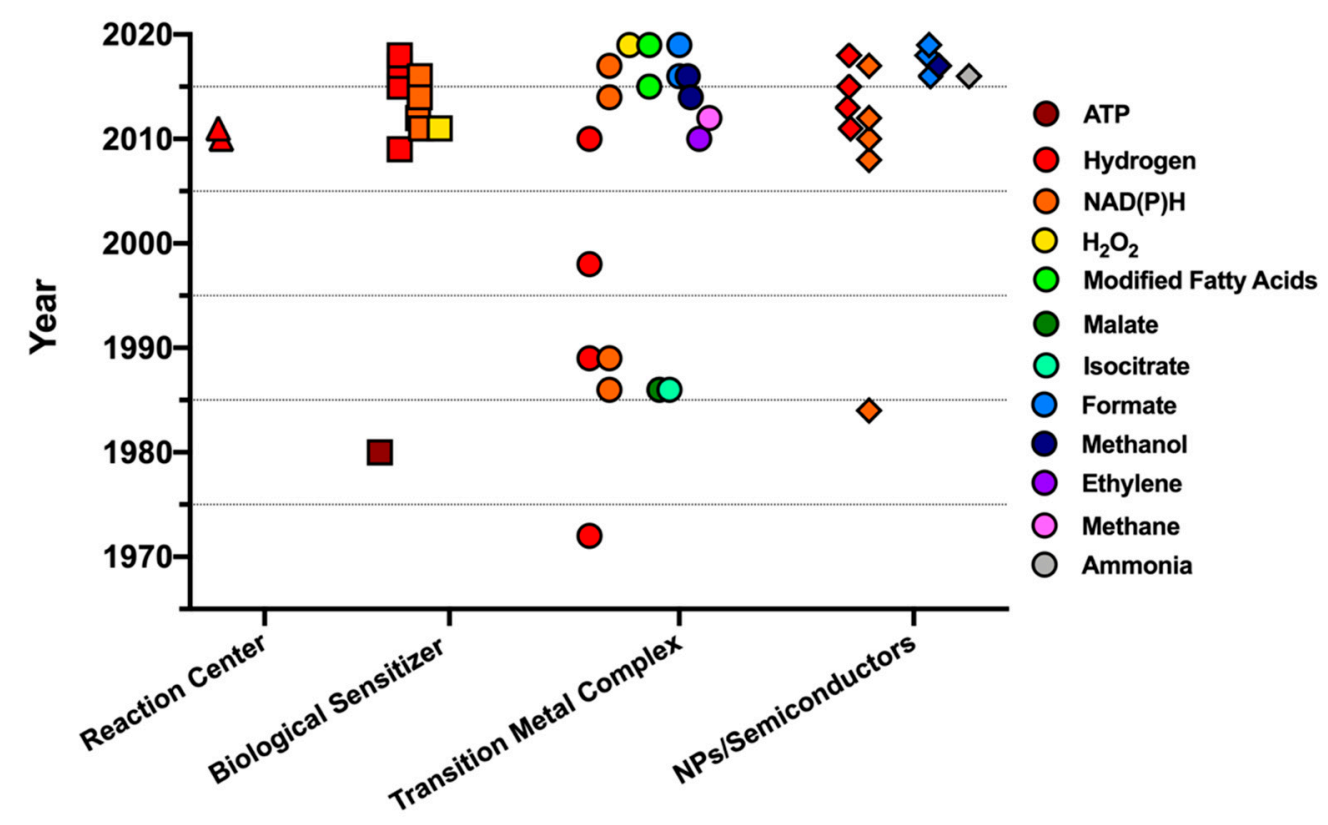

\section{Photoactivation Method}

Figure 6. Timeline of selected biohybrid artificial photosynthetic studies. This has been organized by light active material and targeted catalytic product. Chemical products are color coded and separated by photoactivation method.

\subsection{Light-Driven ATP Synthesis}

A direct result of the chemical processes of oxygenic photosynthesis is the generation of a proton motive force across the thylakoid membrane. The ATP synthase protein complex couples the dissipation of this proton motive force to the synthesis of adenosine triphosphate (ATP). The work of Moore, Moore, Gust and co-workers used artificial reaction centers [125,126] based on covalently linked naphthoquinone, porphyrin, and carotenoid moieties imbedded in a liposomal bilayer [127]. Light capture by the artificial reaction center resulted in acidification of the internal volume of the liposome mediated by the lipophilic quinone mediator. An $\mathrm{F}_{0} \mathrm{~F}_{1}$-ATP synthase imbedded in the liposome catalyzed ATP formation by dissipation of the proton gradient across the lipid bilayer resulting in a 7\% quantum yield. Other types of reaction centers have been shown to produce membrane potential under visible light irradiation though such activity has not yet been coupled to ATP synthesis [123,128-130]. 


\subsection{Bacteriorhodopsin as a Catalyst to Improve Device Performances}

Rhodopsins are a family of light-responsive transmembrane proteins found in Eukaryotes, Archaea, and Bacteria [131]. Of particular interest to biotechnological applications is the well-characterized bacteriorhodopsin (bR), first isolated from Halobacterium salinarum, which functions as light-driven proton pump [132-134]. Both wild-type and mutant strains of bacteriorhodopsin have been used as light absorbers in dye-sensitized solar cells based on $\mathrm{TiO}_{2}$ [135-137] and $\mathrm{ZnO}$ [138] mesoporous semiconductor surfaces. In such applications, the visible light absorption $\left(\lambda_{\max }=568 \mathrm{~nm}\right)$ and good photochemical stability of the bound retinal cofactor make bR a good photosensitizer. Recently, the incorporation of $\mathrm{bR}$ in a methylammonium lead(II) iodide $\left(\mathrm{MAPbI}_{3}\right)$-based perovskite solar cell improved the overall energy conversion compared to the same architecture without bR, with performance gain attributed to a decreased charge carrier recombination in the photoactive layer [139]. Such applications do not directly utilize the light induced proton release activity of bR, though some researchers have taken advantage of this to produce photoelectrochemical devices for generating transient photocurrents induced by changes in the local proton concentrations, of interest in the biosensors and wearable devices fields [140,141].

Both the sensitizer and photon pumping activity of bR has been leveraged in heterogeneous and homogeneous catalytic systems for light-driven hydrogen production. Crystalline [142] and amorphous [143] $\mathrm{TiO}_{2}$ suspensions combined with bR, a sacrificial reductant (e.g., methanol), and $\mathrm{Pt}$ catalyst can generate $\mathrm{H}_{2}$ under illumination with visible light. In a related study, Allam et al. observed a more negative onset potential and increased photocurrent densities with $\mathrm{bR}$ coated $\mathrm{TiO}_{2}$ nanotube-based photoanodes compared to the same electrodes without $\mathrm{bR}$ under photochemical conditions for solar water splitting [144]. Zhao et al. found improved electrochemical and photoelectrochemical activity under cathodic bias of carbon-cloth electrodes with surface-immobilized coating of bR and Ag nanoparticles (AgNP, $\sim 8 \mathrm{~nm}$ diameter) that surpassed that just containing bR or AgNP alone [145].

\subsection{Light-Driven Enzymatic Catalysis by Inorganic Photocatalysts}

Using a light absorber to convert photon energy to oxidizing or reducing equivalents and then transferring this chemical potential energy to a non-photoactive catalyst to drive a chemical process can overcome the difficult challenge of unifying these two processes in a single chemical species [146]. In early demonstrations of this approach, visible light was used to drive the generation of NADPH and coupled to the chiral-specific formation of (-)-2-butanol from 2-butanone using alcohol dehydrogenase [147]. A similar approach using glutamic dehydrogenase formed glutamic acid and the amino acids alanine and aspartic acid [148].

Controlled oxidations can be performed in a similar fashion using alcohol dehydrogenase for substrate-specific oxidations. For instance, cyclohexanol can be converted to cyclohexanone or 2-butanol converted to 2-butanone in a photochemical reactor with NADH formed by alcohol dehydrogenase photochemically oxidized to $\mathrm{NAD}^{+}$using a (tris-bipyridine) ruthenium(II)) light absorber and MV primary acceptor, with the buildup of reduced MV used to drive the production of $\mathrm{H}_{2}$ [149]. Flavin-based light absorbers have been used to drive the photochemical formation of $\mathrm{H}_{2} \mathrm{O}_{2}$ in solution, which in turn serves as co-substrate for the oxyfunctionalization of organic molecules mediated by peroxidase enzymes [150]. Recent work has shown that $\mathrm{Au}-\mathrm{TiO}_{2}$ nanoparticles [151] and tandem semiconductor-based PEC systems [152] can be used for the photochemical generation of $\mathrm{H}_{2} \mathrm{O}_{2}$ from water to drive such enzymatic processes. The photochemical generation of peroxide was similarly coupled to the formation of olefins from the corresponding fatty acid using the enzyme P450 fatty acid decarboxylase [153]. A variety of other reactions have been carried out via enzyme-assisted photocatalysis such as the selective reduction of acetophenones [154], reduction of carbon-carbon double bonds, [155] and lipase catalyzed alkylation reactions [156] with this work detailed in recent review articles [122,124]. A completely inorganic photocatalytic method for production of molecular $\mathrm{H}_{2}$ from glycerol has been recently published, utilizing aluminia-doped $\mathrm{TiO}_{2}$, an example of a fully artificial photosynthetic catalytic process [157]. 


\subsection{Light-Driven Enzyme Systems for $\mathrm{CO}_{2}$ Reduction}

Artificial photosynthesis endeavors to mimic the overall chemistry of converting water (and $\left.\mathrm{CO}_{2}\right)$ to oxygen and a fuel (either $\mathrm{H}_{2}$ or reduced carbon species) with light using technological components [158]. This can entail the exclusive use of inorganic materials $[159,160]$ or some combination of inorganic, organic, and biological substances combined in some organized way [123,161-163]. This section will focus on one particular approach to artificial photosynthesis that involves coupling a non-biological light absorber for the light-driven production of reducing equivalents to drive an enzymatic process resulting in $\mathrm{CO}_{2}$ reduction. Reduction of $\mathrm{CO}_{2}$ to more chemically complex valuable products and fuels has a secondary benefit of carbon sequestration, and could potentially help act as negative emissions technologies to help reduce atmospheric $\mathrm{CO}_{2}$ concentrations, further boosting the potential benefits of these solar technologies.

Early work by Willner and co-workers demonstrated homogeneous light-driven formation of malic acid from pyruvate and $\mathrm{CO}_{2}$ or isocitric acid from oxoglutaric acid and $\mathrm{CO}_{2}$ using NADP-malic enzyme and isocitrate dehydrogenase, respectively [164]. The upstream photochemical steps leading to $\mathrm{CO}_{2}$ fixation involved light absorption by (tris-bipyridine) ruthenium(II) to drive the formation of $\mathrm{NADPH}$ in the presence of a sacrificial donor and ferrodoxin-NADP ${ }^{+}$reductase. Recent work with nanoparticulate semiconductor photocatalysts has demonstrated similar enzyme mediated C-C bond formation with $\mathrm{CO}_{2}$ as a substrate [165].

The photochemical reduction of $\mathrm{CO}_{2}$ to $\mathrm{CO}$ was reported by Armstrong and co-workers using $\mathrm{TiO}_{2}$ nanoparticles with the surface-adsorbed (tris-bipyridine) ruthenium(II) photosensitizer and carbon monoxide dehydrogenase protein [166]. In this approach, the $\mathrm{TiO}_{2}$ semiconductor nanoparticle mediates electron transfer from the synthetic light absorber to the enzyme to drive catalysis, with a sacrificial donor (EDTA or TEOA) consumed in the regeneration of the ground-state ruthenium chromophore. The system demonstrated a turnover of $0.14 \mathrm{~s}^{-1}$ per enzyme over a $4 \mathrm{~h}$ period for the production of $\mathrm{CO}$. Reisner and co-workers have used a similar approach for light-driven formate production from $\mathrm{CO}_{2}$ with a turnover frequency of $11 \mathrm{~s}^{-1}$ [167].

Another biohybrid approach to $\mathrm{CO}_{2}$ reduction involves the light-driven production of NADH [168] or reduced MV [169] to drive the formation of formic acid by formate dehydrogenase. A variety of light absorbers can be used in these systems including organic dyes such as porphyrins [168,170], xanthenes [171], flavins [172], and perylenes [173] as well as visible light-absorbing semiconductors [169,174-176], nanostructured materials [177], polymers [178], and transition metal complexes [179]. If carried out in homogeneous conditions, a sacrificial donor such as ethylenediaminetetraacetic acid (EDTA) or triethanolamine (TEOA) in solution is essential to initiating the photochemical cascade by facilitating the formation of a reducing equivalent from the excited state light absorber. The photogenerated reducing equivalents are used to activate a cocatalyst for driving the production of NADH from NAD ${ }^{+}$, with $\left[\left(\mathrm{Cp}^{*}\right)(\mathrm{bpy}) \mathrm{Rh}\left(\mathrm{OH}_{2}\right)\right]^{2+}\left(\mathrm{Cp}^{*}=\right.$ pentamethylcyclopentadiene, bpy $=2,2^{\prime}$-bipyridine) a commonly employed catalyst $[168,174,180]$. The formation of formic acid in a complete photochemical reactor has been demonstrated, though this system relied on TEOA for the regeneration of NADH equivalents [168]. A recent study used a hematite photoanode with an amorphous cobalt-phosphate water oxidation catalyst to generate reducing equivalents for the enzymatic production of formic acid from $\mathrm{CO}_{2}$ in the cathodic side of the cell [181]. An applied bias of $0.56 \mathrm{~V}$ was required for the onset of photocurrent at $\mathrm{pH}$ 7. However, this approach spatially separates the reduced chemical product from the anodic reactions to prevent non-productive re-oxidation to $\mathrm{CO}_{2}$ which can occur under homogeneous conditions. A similar system with a $\mathrm{BiVO}_{4}$-based photoanode and surface-immobilized enzyme coating on the cathode showed spontaneous photocurrent under pH 7 conditions [182]. As the photocurrent, and therefore rate of production of the reduced product, depends on the photovoltage generated by the PEC under illumination, improved performance has been achieved in enzyme-based PECs by incorporating tandem junctions, such as $\mathrm{BiVO}_{4} /$ perovskite systems $[183,184]$. 
The generation of methanol from $\mathrm{CO}_{2}$ has been pursued using a similar approach as that described above, however, with the additional inclusion of formaldehyde dehydrogenase and alcohol dehydrogenase to the reaction conditions [171]. As each enzyme in the cascade utilizes NADH as a co-substrate, the sequential reduction of $\mathrm{CO}_{2}$ can proceed with a pool of NADH maintained by the presence of a photocatalyst and Rh-based cocatalyst. Baeg and co-workers demonstrated the production of methanol as the only detected product of $\mathrm{CO}_{2}$ reduction with a porphyrin-based photocatalyst for photoregeneration of NADH [185]. Park and co-workers employed this same enzyme cascade in a tandem photoelectrochemical cell with a hematite-based photoanode and bismuth ferrite-based photocathode to achieve methanol production from $\mathrm{CO}_{2}$ with water as the sacrificial source of electrons [186]. While non-spontaneous under illumination, with sufficient applied bias, the photochemical tandem cell produced methanol at an average rate of $1280 \mu \mathrm{mol} \mathrm{g}_{\mathrm{cat}}{ }^{-1} \mathrm{~h}^{-1}$.

\subsection{Light-Activated Nitrogenase}

The reduction of dinitrogen in biology is concomitant with the hydrolysis of ATP. However, several studies have demonstrated the ability to activate the nitrogenase molybdenum-iron protein photochemically. Using a modified (bis-bipyridine)(phenanthroline)ruthenium(II) complex for covalent attachment to nitrogenase, Tezcan and co-workers first showed the ability to drive two electron/two proton reductions, specifically $\mathrm{H}_{2}$ formation or ethylene formation, from acetylene [187]. Subsequent work extended the photochemical activity of the Ru sensitizer-conjugated iron-molybdenum protein to the six-electron reduction of hydrogen cyanide to methane [188]. King and co-works later showed that the use of CdS nanorods could photosensitize surface-adsorbed nitrogenase to drive the formation of ammonia via the eight-electron reduction of $\mathrm{N}_{2}$ with a turnover frequency of $1.25 \mathrm{~s}^{-1}$ [189].

\section{Conclusions}

Herein, we have reported on recent advances in the generation of photocurrents and the generation of solar fuels in biohybrid solar cells utilizing reaction centers. These include PSI, PSII, and the light-harvesting complexes LHCI and LHCII. Several factors must be considered to obtain high photocurrents from biohybrid electrodes and devices. These include electrode material and surface coverage, semiconductor material and architectures, enhancements of reaction center photoexcitation optical cross sections, electron transfer pathways and redox mediators, as well as electrolytes and working conditions. Optimization of nanostructured biohybrid solar cell devices has increased the generated photocurrent and maximizes the potential of utilizing biological photoactive reaction centers as catalysts for energy and valuable product generation.

Hydrogen has long been considered as an alternative for traditional carbon-based fuels. The biological process of photosynthesis has been able to utilize reaction center-catalyzed photochemistry to generate molecular hydrogen with great efficiency, though yields in vivo historically have been low. Emerging approaches and methods to bioengineer greater yields both in vivo and in vitro have been discussed herein, and significant improvements have been made, especially in areas to improve the activity and stability of these photocatalytic biological reaction centers.

The use of native and synthetic reaction centers to generate light-to-electrical energy conversion is a promising technology to help meet growing energy needs in a sustainable, carbon-neutral manner. Taking this technology a step further to produce valuable chemical products by which the converted solar energy may be stored in the form of chemicals bonds is of great interest. These fuels could then be transported and stored for use at times when solar irradiation is not available. This work in the applied photosynthesis field on improving the magnitude of energy production of biologically-based photoelectrochemical devices and yields of valuable products from light-coupled enzymatic catalysis hopes to result in a more environmentally friendly production of valuable products and fuels, and help mitigate the need for utilizing fossil fuels and other unsustainable resources. 
Author Contributions: A.H.T. and B.D.B. conceptualized this review. A.H.T., Z.Y.I., E.-J.O., J.J.B., B.D.S. and B.D.B. all contributed to draft preparation, figure making, and editing. The photocurrent section was written by A.H.T., J.J.B., E.-J.O. and Z.Y.I.; the hydrogen evolution section by A.H.T. and B.D.B.; and the synthetic photosynthesis section by B.D.S. and A.H.T. All authors have read and agreed to the published version of the manuscript.

Funding: A.H.T. and B.D.B. are supported by the Gibson Family Foundation, the Tennessee Plant Research Center, a University of Tennessee at Knoxville (UTK)/Oak Ridge National Laboratory (ORNL) Science Alliance Joint Directed Research Development (JDRD) award to B.D.B., a Donald L. Akers Faculty Enrichment Fellowship to B.D.B., and National Science Foundation support to B.D.B. (DGE-0801470 and EPS-1004083). A.H.T. was supported by an R25 Fellowship from the National Institutes of Health (R25GM086761). All authors have read and agree to the published version of the manuscript.

Acknowledgments: The authors would like to acknowledge the contributions of Khoa Nguyen (UTK) and Michael Vaughn (SpectroLogix, Inc. Knoxville) for their contributions to Figure 5.

Conflicts of Interest: The authors declare no conflict of interest.

\section{References}

1. Kothe, T.; Poller, S.; Zhao, F.; Fortgang, P.; Rogner, M.; Schuhmann, W.; Plumere, N. Engineered electron-transfer chain in photosystem 1 based photocathodes outperforms electron-transfer rates in natural photosynthesis. Chemistry 2014, 20, 11029-11034. [CrossRef] [PubMed]

2. Kazemzadeh, S.; Riazi, G.; Ajeian, R. Novel approach of biophotovoltaic solid state solar cells based on a multilayer of PS1 complexes as an active layer. ACS Sustain. Chem. Eng. 2017, 5, 9836-9840. [CrossRef]

3. Teodor, A.H.; Bruce, B.D. Putting photosystem I to work: Truly green energy. Trends Biotechnol. 2020. [CrossRef] [PubMed]

4. Bennett, T.; Niroomand, H.; Pamu, R.; Ivanov, I.; Mukherjee, D.; Khomami, B. Elucidating the role of methyl viologen as a scavenger of photoactivated electrons from photosystem I under aerobic and anaerobic conditions. Phys. Chem. Chem. Phys. 2016, 18, 8512-8521. [CrossRef] [PubMed]

5. LeBlanc, G.; Gizzie, E.; Yang, S.; Cliffel, D.E.; Jennings, G.K. Photosystem I protein films at electrode surfaces for solar energy conversion. Langmuir 2014, 30, 10990-11001. [CrossRef]

6. Nurnberg, D.J.; Morton, J.; Santabarbara, S.; Telfer, A.; Joliot, P.; Antonaru, L.A.; Ruban, A.V.; Cardona, T.; Krausz, E.; Boussac, A.; et al. Photochemistry beyond the red limit in chlorophyll f-containing photosystems. Science 2018, 360, 1210-1213. [CrossRef]

7. Baker, D.R.; Simmerman, R.F.; Sumner, J.J.; Bruce, B.D.; Lundgren, C.A. Photoelectrochemistry of photosystem I bound in nafion. Langmuir 2014, 30, 13650-13655. [CrossRef]

8. Gordiichuk, P.I.; Rimmerman, D.; Paul, A.; Gautier, D.A.; Gruszka, A.; Saller, M.; de Vries, J.W.; Wetzelaer, G.J.; Manca, M.; Gomulya, W.; et al. Filling the green gap of a megadalton photosystem I complex by conjugation of organic dyes. Bioconjug. Chem. 2016, 27, 36-41. [CrossRef]

9. Balaban, T.S. Tailoring porphyrins and chlorins for self-assembly in biomimetic artificial antenna systems. Acc. Chem. Res. 2005, 38, 612-623. [CrossRef]

10. Linke-Schaetzel, M.; Bhise, A.D.; Gliemann, H.; Koch, T.; Schimmel, T.; Balaban, T.S. Self-assembled chromophores for hybrid solar cells. Thin Solid Films 2004, 451, 16-21. [CrossRef]

11. Gundlach, K.; Werwie, M.; Wiegand, S.; Paulsen, H. Filling the "green gap" of the major light-harvesting chlorophyll a/b complex by covalent attachment of Rhodamine Red. BBA Bioenerg. 2009, 1787, 1499-1504. [CrossRef] [PubMed]

12. Dutta, P.K.; Lin, S.; Loskutov, A.; Levenberg, S.; Jun, D.; Saer, R.; Beatty, J.T.; Liu, Y.; Yan, H.; Woodbury, N.W. Reengineering the optical absorption cross-section of photosynthetic reaction centers. J. Am. Chem. Soc. 2014, 136, 4599-4604. [CrossRef] [PubMed]

13. Nagakawa, H.; Takeuchi, A.; Takekuma, Y.; Noji, T.; Kawakami, K.; Kamiya, N.; Nango, M.; Furukawa, R.; Nagata, M. Efficient hydrogen production using photosystem I enhanced by artificial light harvesting dye. Photochem. Photobiol. Sci. 2019, 18, 309-313. [CrossRef] [PubMed]

14. Carmeli, I.; Lieberman, I.; Kraversky, L.; Fan, Z.; Govorov, A.O.; Markovich, G.; Richter, S. Broad band enhancement of light absorption in photosystem I by metal nanoparticle antennas. Nano Lett. 2010, 10, 2069-2074. [CrossRef] [PubMed]

15. Dervishogullari, D.; Gizzie, E.A.; Jennings, G.K.; Cliffel, D.E. Polyviologen as electron transport material in photosystem I-based biophotovoltaic cells. Langmuir 2018, 34, 15658-15664. [CrossRef] 
16. Mackowski, S.; Wormke, S.; Maier, A.J.; Brotosudarmo, T.H.; Harutyunyan, H.; Hartschuh, A.; Govorov, A.O.; Scheer, H.; Brauchle, C. Metal-enhanced fluorescence of chlorophylls in single light-harvesting complexes. Nano Lett. 2008, 8, 558-564. [CrossRef]

17. Kim, I.; Bender, S.L.; Hranisavljevic, J.; Utschig, L.M.; Huang, L.; Wiederrecht, G.P.; Tiede, D.M. Metal nanoparticle plasmon-enhanced light-harvesting in a photosystem I thin film. Nano Lett. 2011, 11, 3091-3098. [CrossRef]

18. Torres, R.; Diz, V.E.; Lagorio, M.G. Effects of gold nanoparticles on the photophysical and photosynthetic parameters of leaves and chloroplasts. Photochem. Photobiol. Sci. 2018, 17, 505-516. [CrossRef]

19. Niroomand, H.; Pamu, R.; Mukherjee, D.; Khomami, B. Tuning the photocurrent generations from photosystem I assembled in tailored biotic-abiotic interfaces. MRS Commun. 2018, 8, 823-829.

20. Antonacci, A.; Scognamiglio, V. Photosynthesis-based hybrid nanostructures: Electrochemical sensors and photovoltaic cells as case studies. TrAC Trend Anal. Chem. 2019, 115, 100-109. [CrossRef]

21. Murray, C.B.; Kagan, C.R.; Bawendi, M.G. Synthesis and characterization of monodisperse nanocrystals and close-packed nanocrystal assemblies. Annu. Rev. Mater. Sci. 2000, 30, 545-610. [CrossRef]

22. Jung, H.; Gulis, G.; Gupta, S.; Redding, K.; Gosztola, D.J.; Wiederrecht, G.P.; Stroscio, M.A.; Dutta, M. Optical and electrical measurement of energy transfer between nanocrystalline quantum dots and photosystem I. J. Phys. Chem. B 2010, 114, 14544-14549. [CrossRef] [PubMed]

23. Nabiev, I.; Rakovich, A.; Sukhanova, A.; Lukashev, E.; Zagidullin, V.; Pachenko, V.; Rakovich, Y.P.; Donegan, J.F.; Rubin, A.B.; Govorov, A.O. Fluorescent quantum dots as artificial antennas for enhanced light harvesting and energy transfer to photosynthetic reaction centers. Angew. Chem. Int. Ed. 2010, 49, 7217-7221. [CrossRef] [PubMed]

24. Liu, J.T.; Mantell, J.; Di Bartolo, N.; Jones, M.R. Mechanisms of self-assembly and energy harvesting in tuneable conjugates of quantum dots and engineered photovoltaic proteins. Small 2019, 15, 1804267. [CrossRef]

25. Yu, D.; Wang, M.; Zhu, G.; Ge, B.; Liu, S.; Huang, F. Enhanced photocurrent production by bio-dyes of photosynthetic macromolecules on designed $\mathrm{TiO}_{2}$ film. Sci. Rep. 2015, 5, 9375. [CrossRef]

26. Hagfeldt, A.; Boschloo, G.; Sun, L.; Kloo, L.; Pettersson, H. Dye-sensitized solar cells. Chem. Rev. 2010, 110, 6595-6663. [CrossRef]

27. Kondo, M.; Amano, M.; Joke, T.; Ishigure, S.; Noji, T.; Dewa, T.; Amao, Y.; Nango, M. Immobilization of photosystem I or II complexes on electrodes for preparation of photoenergy-conversion devices. Res. Chem. Intermediat. 2014, 40, 3287-3293. [CrossRef]

28. Ciornii, D.; Riedel, M.; Stieger, K.R.; Feifel, S.C.; Hejazi, M.; Lokstein, H.; Zouni, A.; Lisdat, F. Bioelectronic circuit on a 3D electrode architecture: Enzymatic catalysis interconnected with photosystem I. J. Am. Chem. Soc. 2017, 139, 16478-16481. [CrossRef]

29. Riedel, M.; Parak, W.J.; Ruff, A.; Schuhmann, W.; Lisdat, F. Light as trigger for biocatalysis: Photonic Wiring of flavin adenine dinucleotide-dependent glucose dehydrogenase to quantum dot-sensitized inverse opal $\mathrm{TiO}_{2}$ architectures via redox polymers. ACS Catal. 2018, 8, 5212-5220. [CrossRef]

30. Simmerman, R.F.; Zhu, T.; Baker, D.R.; Wang, L.; Mishra, S.R.; Lundgren, C.A.; Bruce, B.D. Engineering photosystem I complexes with metal oxide binding peptides for bioelectronic applications. Bioconjug. Chem. 2015, 26, 2097-2105. [CrossRef]

31. Ocakoglu, K.; Krupnik, T.; van den Bosch, B.; Harputlu, E.; Gullo, M.P.; Olmos, J.D.J.; Yildirimcan, S.; Gupta, R.K.; Yakuphanoglu, F.; Barbieri, A.; et al. Photosystem I-based biophotovoltaics on nanostructured hematite. Adv. Funct. Mater. 2014, 24, 7467-7477. [CrossRef]

32. Gizzie, E.A.; LeBlanc, G.; Jennings, G.K.; Cliffel, D.E. Electrochemical preparation of Photosystem I-polyaniline composite films for biohybrid solar energy conversion. ACS Appl. Mater. Interfaces 2015, 7, 9328-9335. [CrossRef] [PubMed]

33. Robinson, M.T.; Simons, C.E.; Cliffel, D.E.; Jennings, G.K. Photocatalytic photosystem I/PEDOT composite films prepared by vapor-phase polymerization. Nanoscale 2017, 9, 6158-6166. [CrossRef] [PubMed]

34. Feifel, S.C.; Stieger, K.R.; Lokstein, H.; Lux, H.; Lisdat, F. High photocurrent generation by photosystem I on artificial interfaces composed of pi-system-modified graphene. J. Mater. Chem. A 2015, 3, 12188-12196. [CrossRef] 
35. Ciornii, D.; Feifel, S.C.; Hejazi, M.; Kolsch, A.; Lokstein, H.; Zouni, A.; Lisdat, F. Construction of photobiocathodes using multi-walled carbon nanotubes and photosystem I. Phys. Status Solidi A 2017, 214, 1700017. [CrossRef]

36. Feifel, S.C.; Lokstein, H.; Hejazi, M.; Zouni, A.; Lisdat, F. Unidirectional photocurrent of photosystem I on pi-system-modified graphene electrodes: Nanobionic approaches for the construction of photobiohybrid systems. Langmuir 2015, 31, 10590-10598. [CrossRef]

37. Darby, E.; LeBlanc, G.; Gizzie, E.A.; Winter, K.M.; Jennings, G.K.; Cliffel, D.E. Photoactive films of photosystem I on transparent reduced graphene oxide electrodes. Langmuir 2014, 30, 8990-8994. [CrossRef]

38. LeBlanc, G.; Chen, G.; Gizzie, E.A.; Jennings, G.K.; Cliffel, D.E. Enhanced photocurrents of photosystem I films on p-doped silicon. Adv. Mater. 2012, 24, 5959-5962. [CrossRef]

39. Beam, J.C.; LeBlanc, G.; Gizzie, E.A.; Ivanov, B.L.; Needell, D.R.; Shearer, M.J.; Jennings, G.K.; Lukehart, C.M.; Cliffel, D.E. Construction of a semiconductor-biological interface for solar energy conversion: P-doped silicon/photosystem I/Zinc oxide. Langmuir 2015, 31, 10002-10007. [CrossRef]

40. Stieger, K.R.; Feifel, S.C.; Lokstein, H.; Lisdat, F. Advanced unidirectional photocurrent generation via cytochrome $\mathrm{c}$ as reaction partner for directed assembly of photosystem I. Phys. Chem. Chem. Phys. 2014, 16, 15667-15674. [CrossRef]

41. Olmos, J.D.J.; Becquet, P.; Gront, D.; Sar, J.; Dabrowski, A.; Gawlik, G.; Teodorczyk, M.; Pawlak, D.; Kargul, J. Biofunctionalisation of p-doped silicon with cytochrome c(553) minimises charge recombination and enhances photovoltaic performance of the all-solid-state photosystem I-based biophotoelectrode. RSC Adv. 2017, 7, 47854-47866. [CrossRef]

42. Ciesielski, P.N.; Scott, A.M.; Faulkner, C.J.; Berron, B.J.; Cliffel, D.E.; Jennings, G.K. Functionalized nanoporous gold leaf electrode films for the immobilization of photosystem I. ACS Nano 2008, 2, 2465-2472. [CrossRef]

43. Yamanoi, Y.; Terasaki, N.; Miyachi, M.; Inoue, Y.; Nishihara, H. Enhanced photocurrent production by photosystem I with modi fi ed viologen derivatives. Thin Solid Films 2012, 520, 5123-5127. [CrossRef]

44. Yang, S.Y.; Robinson, M.T.; Mwambutsa, F.; Cliffel, D.E.; Jennings, G.K. Effect of cross-linking on the performance and stability of photocatalytic photosystem I films. Electrochim. Acta 2016, 222, $926-932$. [CrossRef]

45. Pang, H.; Zhao, G.; Liu, G.; Zhang, H.; Hai, X.; Wang, S.; Song, H.; Ye, J. Interfacing photosynthetic membrane protein with mesoporous WO3 photoelectrode for solar water oxidation. Small 2018, 14, e1800104. [CrossRef]

46. Ooi, E.J.; Medina, J.; Teodor, A.; Brady, N.; Vaughn, M.; Bruce, B.; Bergkamp, J. Cobalt redox mediators for integration in photosystem I biohybrid solar cells. In Proceedings of the American Chemical Society Meeting, New Orleans, LA, USA, 18-22 March 2018.

47. Zhao, F.; Ruff, A.; Rogner, M.; Schuhmann, W.; Conzuelo, F. Extended operational lifetime of a photosystem-based bioelectrode. J. Am. Chem. Soc. 2019, 141, 5102-5106. [CrossRef] [PubMed]

48. Robinson, M.T.; Cliffel, D.E.; Jennings, G.K. An electrochemical reaction-diffusion model of the photocatalytic effect of photosystem I multilayer films. J. Phys. Chem. B 2018, 122, 117-125. [CrossRef]

49. Zhao, F.; Plumere, N.; Nowaczyk, M.M.; Ruff, A.; Schuhmann, W.; Conzuelo, F. Interrogation of a PS1-based photocathode by means of scanning photoelectrochemical microscopy. Small 2017, 13, 1604093. [CrossRef]

50. Faulkner, C.J.; Lees, S.; Ciesielski, P.N.; Cliffel, D.E.; Jennings, G.K. Rapid assembly of photosystem I monolayers on gold electrodes. Langmuir 2008, 24, 8409-8412. [CrossRef]

51. Ciesielski, P.N.; Hijazi, F.M.; Scott, A.M.; Faulkner, C.J.; Beard, L.; Emmett, K.; Rosenthal, S.J.; Cliffel, D.; Jennings, G.K. Photosystem I-Based biohybrid photoelectrochemical cells. Bioresour. Technol. 2010, 101, 3047-3053. [CrossRef]

52. Gizzie, E.A.; Niezgoda, J.S.; Robinson, M.T.; Harris, A.G.; Jennings, G.K.; Rosenthal, S.J.; Cliffel, D.E. Photosystem I-polyaniline/ $/ \mathrm{TiO}_{2}$ solid-state solar cells: Simple devices for biohybrid solar energy conversion. Energy Environ. Sci. 2015, 8, 3572-3576. [CrossRef]

53. Shah, V.B.; Henson, W.R.; Chadha, T.S.; Lakin, G.; Liu, H.J.; Blankenship, R.E.; Biswas, P. Linker-free deposition and adhesion of photosystem i onto nanostructured $\mathrm{TiO}_{2}$ for biohybrid photoelectrochemical cells. Langmuir 2015, 31, 1675-1682. [CrossRef] [PubMed]

54. Stieger, K.R.; Feifel, S.C.; Lokstein, H.; Hejazi, M.; Zouni, A.; Lisdat, F. Biohybrid architectures for efficient light-to-current conversion based on photosystem I within scalable 3D mesoporous electrodes. J. Mater. Chem. A 2016, 4, 17009-17017. [CrossRef] 
55. Cadirci, B.H. An electricity production study by Rhodobacter sphaeroides. Int. J. Hydrog. Energy 2018, 43, 18001-18006. [CrossRef]

56. Csiki, R.; Drieschner, S.; Lyuleeva, A.; Cattani-Scholz, A.; Stutzmann, M.; Garrido, J.A. Photocurrent generation of biohybrid systems based on bacterial reaction centers and graphene electrodes. Diam. Relat. Mater. 2018, 89, 286-292. [CrossRef]

57. Wenzel, T.; Hartter, D.; Bombelli, P.; Howe, C.J.; Steiner, U. Porous translucent electrodes enhance current generation from photosynthetic biofilms. Nat. Commun. 2018, 9, 1299. [CrossRef]

58. Wey, L.T.; Bombelli, P.; Chen, X.; Lawrence, J.M.; Rabideau, C.M.; Rowden, S.J.L.; Zhang, J.Z.; Howe, C.J. The development of biophotovoltaic systems for power generation and biological analysis. ChemElectroChem 2019, 6, 5375-5386. [CrossRef]

59. Kavadiya, S.; Chadha, T.S.; Liu, H.; Shah, V.B.; Blankenship, R.E.; Biswas, P. Directed assembly of the thylakoid membrane on nanostructured $\mathrm{TiO}_{2}$ for a photo-electrochemical cell. Nanoscale 2016, 8, 1868-1872. [CrossRef]

60. Zeynali, A.; Ghiasi, T.S.; Riazi, G.; Ajeian, R. Organic solar cell based on photosystem I pigment-protein complex, fabrication and optimization. Org. Electron. 2017, 51, 341-348. [CrossRef]

61. Gaffron, H. Reduction of carbon dioxide with molecular hydrogen in green algae. Nature 1939, 143, $204-205$. [CrossRef]

62. Stuart, T.S.; Gaffron, H. Mechanism of hydrogen photoproduction by several algae: II. Contribution of Photosystem-Ii. Planta 1972, 106, 101-112. [CrossRef] [PubMed]

63. Greenbaum, E. Photosynthetic unit of hydrogen evolution. Science 1977, 196, 879-880. [CrossRef] [PubMed]

64. Greenbaum, E. Simultaneous photoproduction of hydrogen and oxygen by photosynthesis. Biotechnol. Bioeng. 1980, 22, 1-13.

65. Maione, T.E.; Gibbs, M. Hydrogenase-mediated activities in isolated chloroplasts of chlamydomonas reinhardii. Plant Physiol. 1986, 80, 360-363. [CrossRef] [PubMed]

66. Wunschiers, R.; Stangier, K.; Senger, H.; Schulz, R. Molecular evidence for a Fe-hydrogenase in the green alga Scenedesmus obliquus. Curr. Microbiol. 2001, 42, 353-360. [CrossRef]

67. Winkler, M.; Heil, B.; Happe, T. Isolation and molecular characterization of the [Fe]-hydrogenase from the unicellular green alga Chlorella fusca. Biochim. Biophys. Acta 2002, 1576, 330-334. [CrossRef]

68. Florin, L.; Tsokoglou, A.; Happe, T. A novel type of iron hydrogenase in the green alga Scenedesmus obliquus is linked to the photosynthetic electron transport chain. J. Biol. Chem. 2001, 276, 6125-6132. [CrossRef]

69. Ludwig, M.; Schulz-Friedrich, R.; Appel, J. Occurrence of hydrogenases in cyanobacteria and anoxygenic photosynthetic bacteria: Implications for the phylogenetic origin of cyanobacterial and algal hydrogenases. J. Mol. Evol. 2006, 63, 758-768. [CrossRef]

70. Ghirardi, M.L.; Posewitz, M.C.; Maness, P.C.; Dubini, A.; Yu, J.; Seibert, M. Hydrogenases and hydrogen photoproduction in oxygenic photosynthetic organisms. Annu. Rev. Plant Biol. 2007, 58, 71-91. [CrossRef]

71. Peters, J.W.; Schut, G.J.; Boyd, E.S.; Mulder, D.W.; Shepard, E.M.; Broderick, J.B.; King, P.W.; Adams, M.W. [FeFe]- and [NiFe]-hydrogenase diversity, mechanism, and maturation. Biochim. Biophys. Acta 2015, 1853, 1350-1369. [CrossRef]

72. Morra, S.; Arizzi, M.; Valetti, F.; Gilardi, G. Oxygen stability in the new [FeFe]-hydrogenase from clostridium beijerinckii SM10 (CbA5H). Biochemistry 2016, 55, 5897-5900. [CrossRef] [PubMed]

73. Iwuchukwu, I.J.; Vaughn, M.; Myers, N.; O’Neill, H.; Frymier, P.; Bruce, B.D. Self-organized photosynthetic nanoparticle for cell-free hydrogen production. Nat. Nanotechnol. 2010, 5, 73-79. [CrossRef] [PubMed]

74. Khanna, N.; Lindblad, P. Cyanobacterial hydrogenases and hydrogen metabolism revisited: Recent progress and future prospects. Int. J. Mol. Sci. 2015, 16, 10537-10561. [CrossRef] [PubMed]

75. Greenbaum, E. Photosynthetic hydrogen and oxygen production: Kinetic studies. Science 1982, 215, $291-293$. [CrossRef] [PubMed]

76. Greenbaum, E.; Guillard, R.R.L.; Sunda, W.G. Hydrogen and oxygen photoproduction by marine-algae. Photochem. Photobiol. 1983, 37, 649-655. [CrossRef]

77. Greenbaum, E. Energetic efficiency of hydrogen photoevolution by algal water splitting. Biophys. J. 1988, 54, 365-368. [CrossRef]

78. Stuart, T.S.; Gaffron, H. Kinetics of hydrogen photoproduction by adapted scenedesmus. Planta 1971, 100, 228-243. [CrossRef] [PubMed]

79. Stuart, T.S.; Gaffron, H. Kinetics of $\mathrm{H}_{2}$ photoproduction by scenedesmus. Plant Physiol. 1971, 47, 32. 
80. Stuart, T.S.; Gaffron, H. Mechanism of hydrogen photoproduction by several algae: I. Effect of inhibitors of photophosphorylation. Planta 1972, 106, 91-100. [CrossRef] [PubMed]

81. Benemann, J.R.; Berenson, J.A.; Kaplan, N.O.; Kamen, M.D. Hydrogen evolution by a chloroplast-ferredoxin-hydrogenase system. Proc. Natl. Acad. Sci. USA 1973, 70, 2317-2320. [CrossRef] [PubMed]

82. Melis, A.; Zhang, L.; Forestier, M.; Ghirardi, M.L.; Seibert, M. Sustained photobiological hydrogen gas production upon reversible inactivation of oxygen evolution in the green alga Chlamydomonas reinhardtii. Plant Physiol. 2000, 122, 127-136. [CrossRef] [PubMed]

83. Melis, A. Photosynthetic $\mathrm{H}_{2}$ metabolism in Chlamydomonas reinhardtii (unicellular green algae). Planta 2007, 226, 1075-1086. [CrossRef] [PubMed]

84. Liran, O.; Semyatich, R.; Milrad, Y.; Eilenberg, H.; Weiner, I.; Yacoby, I. Microoxic niches within the thylakoid stroma of air-grown chlamydomonas reinhardtii protect [FeFe]-hydrogenase and support hydrogen production under fully aerobic environment. Plant Physiol. 2016, 172, 264-271. [CrossRef]

85. Saper, G.; Kallmann, D.; Conzuelo, F.; Zhao, F.; Toth, T.N.; Liveanu, V.; Meir, S.; Szymanski, J.; Aharoni, A.; Schuhmann, W.; et al. Live cyanobacteria produce photocurrent and hydrogen using both the respiratory and photosynthetic systems. Nat. Commun. 2018, 9, 2168. [CrossRef] [PubMed]

86. Fang, X.; Kalathil, S.; Reisner, E. Semi-biological approaches to solar-to-chemical conversion. Chem. Soc. Rev. 2020, 49, 4926-4952. [CrossRef]

87. Evans, B.R.; O’Neill, H.M.; Hutchens, S.A.; Bruce, B.D.; Greenbaum, E. Enhanced photocatalytic hydrogen evolution by covalent attachment of plastocyanin to photosystem I. Nano Lett. 2004, 4, 1815-1819. [CrossRef]

88. Lubner, C.E.; Applegate, A.M.; Knorzer, P.; Ganago, A.; Bryant, D.A.; Happe, T.; Golbeck, J.H. Solar hydrogen-producing bionanodevice outperforms natural photosynthesis. Proc. Natl. Acad. Sci. USA 2011, 108, 20988-20991. [CrossRef]

89. Hohner, R.; Pribil, M.; Herbstova, M.; Lopez, L.S.; Kunz, H.H.; Li, M.; Wood, M.; Svoboda, V.; Puthiyaveetil, S.; Leister, D.; et al. Plastocyanin is the long-range electron carrier between photosystem II and photosystem I in plants. Proc. Natl. Acad. Sci. USA 2020, 117, 15354-15362. [CrossRef]

90. Kovalenko, I.B.; Knyazeva, O.S.; Antal, T.K.; Ponomarev, V.Y.; Riznichenko, G.Y.; Rubin, A.B. Multiparticle Brownian dynamics simulation of experimental kinetics of cytochrome bf oxidation and photosystem I reduction by plastocyanin. Physiol. Plant. 2017, 161, 88-96. [CrossRef]

91. Ihara, M.; Nishihara, H.; Yoon, K.S.; Lenz, O.; Friedrich, B.; Nakamoto, H.; Kojima, K.; Honma, D.; Kamachi, T.; Okura, I. Light-driven hydrogen production by a hybrid complex of a [NiFe]-hydrogenase and the cyanobacterial photosystem I. Photochem. Photobiol. 2006, 82, 676-682. [CrossRef]

92. Appel, J.; Hueren, V.; Boehm, M.; Gutekunst, K. Cyanobacterial in vivo solar hydrogen production using a photosystem I-hydrogenase (PsaD-HoxYH) fusion complex. Nat. Energy 2020, 5, 458-467. [CrossRef]

93. Eilenberg, H.; Weiner, I.; Ben-Zvi, O.; Pundak, C.; Marmari, A.; Liran, O.; Wecker, M.S.; Milrad, Y.; Yacoby, I. The dual effect of a ferredoxin-hydrogenase fusion protein in vivo: Successful divergence of the photosynthetic electron flux towards hydrogen production and elevated oxygen tolerance. Biotechnol. Biofuels 2016, 9, 182. [CrossRef] [PubMed]

94. Kanygin, A.; Milrad, Y.; Thummala, C.; Reifschneider, K.; Baker, P.; Marco, P.; Yacoby, I.; Redding, K.E. Rewiring photosynthesis: A photosystem I-hydrogenase chimera that makes $\mathrm{H}_{2}$ in vivo. Energy Environ. Sci. 2020. [CrossRef]

95. Utschig, L.M.; Soltau, S.R.; Tiede, D.M. Light-driven hydrogen production from Photosystem I-catalyst hybrids. Curr. Opin. Chem. Biol. 2015, 25, 1-8. [CrossRef] [PubMed]

96. Lee, I.; Lee, J.W.; Stubna, A.; Greenbaum, E. Measurement of electrostatic potentials above oriented single photosynthetic reaction centers. J. Phys. Chem. B 2000, 104, 2439-2443. [CrossRef]

97. Brettel, K. Electron transfer and arrangement of the redox cofactors in photosystem I. Biochim. Biophys. Acta Bioenerg. 1997, 1318, 322-373. [CrossRef]

98. Zankel, K.L.; Reed, D.W.; Clayton, R.K. Fluorescence and photochemical quenching in photosynthetic reaction centers. Proc. Natl. Acad. Sci. USA 1968, 61, 1243. [CrossRef]

99. Hiyama, T. Quantum yield and requirement for the photooxidation of P-700. Physiol. Veg. 1985, 23, 605-610.

100. Millsaps, J.F.; Bruce, B.D.; Lee, J.W.; Greenbaum, E. Nanoscale photosynthesis: Photocatalytic production of hydrogen by platinized photosystem I reaction centers. Photochem. Photobiol. 2001, 73, 630-635. [CrossRef] 
101. Ihara, M.; Nakamoto, H.; Kamachi, T.; Okura, I.; Maeda, M. Photoinduced hydrogen production by direct electron transfer from photosystem I cross-linked with cytochrome $\mathrm{c} 3$ to [NiFe]-hydrogenase. Photochem. Photobiol. 2006, 82, 1677-1685. [CrossRef]

102. Greenbaum, E. Platinized chloroplasts: A novel photocatalytic material. Science 1985, 230, $1373-1375$. [CrossRef] [PubMed]

103. Grimme, R.A.; Lubner, C.E.; Bryant, D.A.; Golbeck, J.H. Photosystem I/molecular wire/metal nanoparticle bioconjugates for the photocatalytic production of H-2. J. Am. Chem. Soc. 2008, 130, 6308-6309. [CrossRef] [PubMed]

104. Zhao, F.; Conzuelo, F.; Hartmann, V.; Li, H.; Nowaczyk, M.M.; Plumere, N.; Rogner, M.; Schuhmann, W. Light Induced $\mathrm{H}_{2}$ evolution from a biophotocathode based on photosystem 1-Pt nanoparticles complexes integrated in solvated redox polymers films. J. Phys. Chem. B 2015, 119, 13726-13731. [CrossRef] [PubMed]

105. Applegate, A.M.; Lubner, C.E.; Knörzer, P.; Happe, T.; Golbeck, J.H. Quantum yield measurements of light-induced $\mathrm{H}_{2}$ generation in a photosystem I-[FeFe]- $\mathrm{H}_{2}$ ase nanoconstruct. Photosynth. Res. 2016, 127, 5-11. [CrossRef]

106. Ban, S.; Lin, W.; Luo, Z.; Luo, J. Improving hydrogen production of Chlamydomonas reinhardtii by reducing chlorophyll content via atmospheric and room temperature plasma. Bioresour. Technol. 2019, 275, 425-429. [CrossRef]

107. Kiley, P.; Zhao, X.; Vaughn, M.; Baldo, M.A.; Bruce, B.D.; Zhang, S. Self-assembling peptide detergents stabilize isolated photosystem I on a dry surface for an extended time. PLoS Biol. 2005, 3, e230. [CrossRef]

108. Prince, R.C.; Kheshgi, H.S. The photobiological production of hydrogen: Potential efficiency and effectiveness as a renewable fuel. Crit. Rev. Microbiol. 2005, 31, 19-31. [CrossRef]

109. Lam, E.; Malkin, R. Reconstruction of the chloroplast noncyclic electron transport pathway from water to NADP with three integral protein complexes. Proc. Natl. Acad. Sci. USA 1982, 79, 5494-5498. [CrossRef]

110. Pernil, R.; Schleiff, E. Metalloproteins in the biology of heterocysts. Life 2019, 9, 32. [CrossRef]

111. Queiroz, M.I.; Vieira, J.G.; Maroneze, M.M. Morphophysiological, structural, and metabolic aspects of microalgae. In Handbook of Microalgae-Based Processes and Products; Elsevier: Amsterdam, The Netherlands, 2020; pp. 25-48. [CrossRef]

112. Swainsbury, D.J.; Scheidelaar, S.; van Grondelle, R.; Killian, J.A.; Jones, M.R. Bacterial reaction centers purified with styrene maleic acid copolymer retain native membrane functional properties and display enhanced stability. Angew. Chem. Int. Ed. Engl. 2014, 53, 11803-11807. [CrossRef]

113. Brady, N.G.; Li, M.; Ma, Y.; Gumbart, J.C.; Bruce, B.D. Non-detergent isolation of a cyanobacterial photosystem I using styrene maleic acid alternating copolymers. RSC Adv. 2019, 9, 31781-31796. [CrossRef]

114. Sun, C.; Benlekbir, S.; Venkatakrishnan, P.; Wang, Y.; Hong, S.; Hosler, J.; Tajkhorshid, E.; Rubinstein, J.L.; Gennis, R.B. Structure of the alternative complex III in a supercomplex with cytochrome oxidase. Nature 2018, 557, 123-126. [CrossRef] [PubMed]

115. Schmidt, V.; Sturgis, J.N. Modifying styrene-maleic acid co-polymer for studying lipid nanodiscs. Biochim. Biophys. Acta Biomembr. 2018, 1860, 777-783. [CrossRef]

116. Wheatley, M.; Charlton, J.; Jamshad, M.; Routledge, S.J.; Bailey, S.; La-Borde, P.J.; Azam, M.T.; Logan, R.T.; Bill, R.M.; Dafforn, T.R.; et al. GPCR-styrene maleic acid lipid particles (GPCR-SMALPs): Their nature and potential. Biochem. Soc. Trans. 2016, 44, 619-623. [CrossRef]

117. Gulamhussein, A.A.; Meah, D.; Soja, D.D.; Fenner, S.; Saidani, Z.; Akram, A.; Lallie, S.; Mathews, A.; Painter, C.; Liddar, M.K.; et al. Examining the stability of membrane proteins within SMALPs. Eur. Polym. J. 2019, 112, 120-125. [CrossRef]

118. Cherepanov, D.A.; Brady, N.G.; Shelaev, I.V.; Nguyen, J.; Gostev, F.E.; Mamedov, M.D.; Nadtochenko, V.A.; Bruce, B.D. PSI-SMALP, a detergent-free cyanobacterial photosystem I, reveals faster femtosecond photochemistry. Biophys. J. 2020, 118, 337-351. [CrossRef] [PubMed]

119. Kruger, A.; Schafers, C.; Schroder, C.; Antranikian, G. Towards a sustainable biobased industry—Highlighting the impact of extremophiles. N. Biotechnol. 2018, 40, 144-153. [CrossRef]

120. Spieck, E.; Spohn, M.; Wendt, K.; Bock, E.; Shively, J.; Frank, J.; Indenbirken, D.; Alawi, M.; Lucker, S.; Hupeden, J. Extremophilic nitrite-oxidizing Chloroflexi from Yellowstone hot springs. ISME J. 2020, 14, 364-379. [CrossRef]

121. Shrestha, N.; Chilkoor, G.; Vemuri, B.; Rathinam, N.; Sani, R.K.; Gadhamshetty, V. Extremophiles for microbial-electrochemistry applications: A critical review. Bioresour. Technol. 2018, 255, 318-330. [CrossRef] 
122. Macia-Agullo, J.A.; Corma, A.; Garcia, H. Photobiocatalysis: The power of combining photocatalysis and enzymes. Chemistry 2015, 21, 10940-10959. [CrossRef]

123. Fukuzumi, S.; Lee, Y.M.; Nam, W. Artificial photosynthesis for production of ATP, NAD(P)H, and hydrogen peroxide. ChemPhotoChem 2017, 2, 121-135. [CrossRef]

124. Lee, S.H.; Choi, D.S.; Kuk, S.K.; Park, C.B. Photobiocatalysis: Activating redox enzymes by direct or indirect transfer of photoinduced electrons. Angew. Chem. Int. Ed. Engl. 2018, 57, 7958-7985. [CrossRef] [PubMed]

125. Gust, D.; Moore, T.A.; Moore, A.L. Solar fuels via artificial photosynthesis. Acc. Chem. Res. 2009, 42, 1890-1898. [CrossRef]

126. Sherman, B.D.; Vaughn, M.D.; Bergkamp, J.J.; Gust, D.; Moore, A.L.; Moore, T.A. Evolution of reaction center mimics to systems capable of generating solar fuel. Photosynth. Res. 2014, 120, 59-70. [CrossRef] [PubMed]

127. Steinberg-Yfrach, G.; Rigaud, J.L.; Durantini, E.N.; Moore, A.L.; Gust, D.; Moore, T.A. Light-driven production of ATP catalysed by F0F1-ATP synthase in an artificial photosynthetic membrane. Nature 1998, 392, 479-482. [CrossRef] [PubMed]

128. Numata, T.; Murakami, T.; Kawashima, F.; Morone, N.; Heuser, J.E.; Takano, Y.; Ohkubo, K.; Fukuzumi, S.; Mori, Y.; Imahori, H. Utilization of photoinduced charge-separated state of donor-acceptor-linked molecules for regulation of cell membrane potential and ion transport. J. Am. Chem. Soc. 2012, 134, 6092-6095. [CrossRef]

129. Bhosale, S.; Sisson, A.L.; Talukdar, P.; Furstenberg, A.; Banerji, N.; Vauthey, E.; Bollot, G.; Mareda, J.; Roger, C.; Wurthner, F; et al. Photoproduction of proton gradients with pi-stacked fluorophore scaffolds in lipid bilayers. Science 2006, 313, 84-86. [CrossRef]

130. Hvasanov, D.; Peterson, J.R.; Thordarson, P. Self-assembled light-driven photosynthetic-respiratory electron transport chain hybrid proton pump. Chem. Sci. 2013, 4, 3833-3838. [CrossRef]

131. Ernst, O.P.; Lodowski, D.T.; Elstner, M.; Hegemann, P.; Brown, L.S.; Kandori, H. Microbial and animal rhodopsins: Structures, functions, and molecular mechanisms. Chem. Rev. 2014, 114, 126-163. [CrossRef]

132. Schulten, K.; Tavan, P. A mechanism for the light-driven proton pump of Halobacterium halobium. Nature 1978, 272, 85-86. [CrossRef]

133. Mahyad, B.; Janfaza, S.; Hosseini, E.S. Bio-nano hybrid materials based on bacteriorhodopsin: Potential applications and future strategies. Adv. Colloid Interface Sci. 2015, 225, 194-202. [CrossRef] [PubMed]

134. Li, Y.T.; Tian, Y.; Tian, H.; Tu, T.; Gou, G.Y.; Wang, Q.; Qiao, Y.C.; Yang, Y.; Ren, T.L. A review on bacteriorhodopsin-based bioelectronic devices. Sensors 2018, 18, 1368. [CrossRef] [PubMed]

135. Thavasi, V.; Lazarova, T.; Filipek, S.; Kolinski, M.; Querol, E.; Kumar, A.; Ramakrishna, S.; Padros, E.; Renugopalakrishnan, V. Study on the feasibility of bacteriorhodopsin as bio-photosensitizer in excitonic solar cell: A first report. J. Nanosci. Nanotechnol. 2009, 9, 1679-1687. [CrossRef] [PubMed]

136. Renugopalakrishnan, V.; Barbiellini, B.; King, C.; Molinari, M.; Mochalov, K.; Sukhanova, A.; Nabiev, I.; Fojan, P.; Tuller, H.L.; Chin, M.; et al. Engineering a robust photovoltaic device with quantum dots and bacteriorhodopsin. J. Phys. Chem. C Nanomater. Interfaces 2014, 118, 16710-16717. [CrossRef]

137. Mohammadpour, R.; Janfaza, S. Efficient nanostructured biophotovoltaic cell based on bacteriorhodopsin as biophotosensitizer. ACS Sustain. Chem. Eng. 2015, 3, 809-813. [CrossRef]

138. Molaeirad, A.; Rezaeian, N. Oriented assembly of bacteriorhodopsin on ZnO nanostructured electrode for enhanced photocurrent generation. Biotechnol. Appl. Biochem. 2015, 62, 489-493. [CrossRef]

139. Das, S.; Wu, C.; Song, Z.; Hou, Y.; Koch, R.; Somasundaran, P.; Priya, S.; Barbiellini, B.; Venkatesan, R. Bacteriorhodopsin enhances efficiency of perovskite solar cells. ACS Appl. Mater. Interfaces 2019, 11, 30728-30734. [CrossRef]

140. Chu, L.K.; Yen, C.W.; El-Sayed, M.A. Bacteriorhodopsin-based photo-electrochemical cell. Biosens. Bioelectron. 2010, 26, 620-626. [CrossRef]

141. Yen, C.W.; Hayden, S.C.; Dreaden, E.C.; Szymanski, P.; El-Sayed, M.A. Tailoring plasmonic and electrostatic field effects to maximize solar energy conversion by bacteriorhodopsin, the other natural photosynthetic system. Nano Lett. 2011, 11, 3821-3826. [CrossRef]

142. Balasubramanian, S.; Wang, P.; Schaller, R.D.; Rajh, T.; Rozhkova, E.A. High-performance bioassisted nanophotocatalyst for hydrogen production. Nano Lett. 2013, 13, 3365-3371. [CrossRef]

143. Johnson, K.E.; Gakhar, S.; Risbud, S.H.; Longo, M.L. Development and characterization of titanium dioxide gel with encapsulated bacteriorhodopsin for hydrogen production. Langmuir 2018, 34, 7488-7496. [CrossRef] 
144. Allam, N.K.; Yen, C.-W.; Near, R.D.; El-Sayed, M.A. Bacteriorhodopsin/ $\mathrm{TiO}_{2}$ nanotube arrays hybrid system for enhanced photoelectrochemical water splitting. Energy Environ. Sci. 2011, 4, 2909-2914. [CrossRef]

145. Zhao, Z.; Wang, P.; Xu, X.; Sheves, M.; Jin, Y. Bacteriorhodopsin/Ag nanoparticle-based hybrid nano-bio electrocatalyst for efficient and robust $\mathrm{H}_{2}$ evolution from water. J. Am. Chem. Soc. 2015, 137, 2840-2843. [CrossRef] [PubMed]

146. Skubi, K.L.; Blum, T.R.; Yoon, T.P. Dual catalysis strategies in photochemical synthesis. Chem. Rev. 2016, 116, 10035-10074. [CrossRef] [PubMed]

147. Mandler, D.; Willner, I. Solar light induced formation of chiral 2-butanol in an enzyme-catalyzed chemical system. J. Am. Chem. Soc. 1984, 106, 5352-5353. [CrossRef]

148. Mandler, D.; Willner, I. Photoinduced enzyme-catalysed synthesis of amino acids by visible light. J. Chem. Soc. Chem. Commun. 1986, 851-853. [CrossRef]

149. Ruppert, R.; Steckhan, E. Efficient photoelectrochemical in-situ regeneration of NAD $(P)+$ coupled to enzymatic oxidation of alcohols. J. Chem. Soc. Perkin Trans. 2 1989, 811-814. [CrossRef]

150. Gandomkar, S.; Dennig, A.; Dordic, A.; Hammerer, L.; Pickl, M.; Haas, T.; Hall, M.; Faber, K. Biocatalytic oxidative cascade for the conversion of fatty acids into alpha-ketoacids via internal $\mathrm{H}_{2} \mathrm{O}_{2}$ recycling. Angew. Chem. Int. Ed. Engl. 2018, 57, 427-430. [CrossRef]

151. Zhang, W.; Fernandez-Fueyo, E.; Ni, Y.; van Schie, M.; Gacs, J.; Renirie, R.; Wever, R.; Mutti, F.G.; Rother, D.; Alcalde, M.; et al. Selective aerobic oxidation reactions using a combination of photocatalytic water oxidation and enzymatic oxyfunctionalisations. Nat. Catal. 2018, 1, 55-62. [CrossRef]

152. Choi, D.S.; Lee, H.; Tieves, F.; Lee, Y.W.; Son, E.J.; Zhang, W.; Shin, B.; Hollmann, F.; Park, C.B. Bias-free in situ $\mathrm{H}_{2} \mathrm{O}_{2}$ generation in a photovoltaic-photoelectrochemical tandem cell for biocatalytic oxyfunctionalization. ACS Catal. 2019, 9, 10562-10566. [CrossRef]

153. Zachos, I.; Gassmeyer, S.K.; Bauer, D.; Sieber, V.; Hollmann, F.; Kourist, R. Photobiocatalytic decarboxylation for olefin synthesis. Chem. Commun. 2015, 51, 1918-1921. [CrossRef] [PubMed]

154. Choudhury, S.; Baeg, J.O.; Park, N.J.; Yadav, R.K. A photocatalyst/enzyme couple that uses solar energy in the asymmetric reduction of acetophenones. Angew. Chem. Int. Ed. Engl. 2012, 51, 11624-11628. [CrossRef] [PubMed]

155. Hutton, G.A.; Reuillard, B.; Martindale, B.C.; Caputo, C.A.; Lockwood, C.W.; Butt, J.N.; Reisner, E. Carbon dots as versatile photosensitizers for solar-driven catalysis with redox enzymes. J. Am. Chem. Soc. 2016, 138, 16722-16730. [CrossRef] [PubMed]

156. Ding, X.; Dong, C.L.; Guan, Z.; He, Y.H. Concurrent asymmetric reactions combining photocatalysis and enzyme catalysis: Direct enantioselective synthesis of 2,2-disubstituted indol-3-ones from 2-arylindoles. Angew. Chem. Int. Ed. Engl. 2019, 58, 118-124. [CrossRef]

157. Osman, A.I.; Skillen, N.C.; Robertson, P.K.J.; Rooney, D.W.; Morgan, K. Exploring the photocatalytic hydrogen production potential of titania doped with alumina derived from foil waste. Int. J. Hydrog. Energy 2020. [CrossRef]

158. Bard, A.J.; Fox, M.A. Artificial photosynthesis: Solar splitting of water to hydrogen and oxygen. Acc. Chem. Res. 1995, 28, 141-145. [CrossRef]

159. Fujishima, A.; Honda, K. Electrochemical photolysis of water at a semiconductor electrode. Nature 1972, 238, 37-38. [CrossRef]

160. Khaselev, O. A Monolithic photovoltaic-photoelectrochemical device for hydrogen production via water splitting. Science 1998, 280, 425-427. [CrossRef]

161. Ashford, D.L.; Gish, M.K.; Vannucci, A.K.; Brennaman, M.K.; Templeton, J.L.; Papanikolas, J.M.; Meyer, T.J. Molecular chromophore-catalyst assemblies for solar fuel applications. Chem. Rev. 2015, 115, 13006-13049. [CrossRef]

162. Xu, P.; McCool, N.S.; Mallouk, T.E. Water splitting dye-sensitized solar cells. Nano Today 2017, 14, 42-58. [CrossRef]

163. Hambourger, M.; Moore, G.F.; Kramer, D.M.; Gust, D.; Moore, A.L.; Moore, T.A. Biology and technology for photochemical fuel production. Chem. Soc. Rev. 2009, 38, 25-35. [CrossRef] [PubMed]

164. Willner, I.; Mandler, D.; Riklin, A. Photoinduced carbon dioxide fixation forming malic and isocitric acid. J. Chem. Soc. Chem. Commun. 1986, 1022-1024. [CrossRef] 
165. Hamby, H.; Li, B.; Shinopoulos, K.E.; Keller, H.R.; Elliott, S.J.; Dukovic, G. Light-driven carbon-carbon bond formation via $\mathrm{CO}_{2}$ reduction catalyzed by complexes of $\mathrm{CdS}$ nanorods and a 2-oxoacid oxidoreductase. Proc. Natl. Acad. Sci. USA 2020, 117, 135-140. [CrossRef] [PubMed]

166. Woolerton, T.W.; Sheard, S.; Pierce, E.; Ragsdale, S.W.; Armstrong, F.A. $\mathrm{CO}_{2}$ photoreduction at enzyme-modified metal oxide nanoparticles. Energy Environ. Sci. 2011, 4, 2393-2399. [CrossRef]

167. Miller, M.; Robinson, W.E.; Oliveira, A.R.; Heidary, N.; Kornienko, N.; Warnan, J.; Pereira, I.A.C.; Reisner, E. Interfacing formate dehydrogenase with metal oxides for the reversible electrocatalysis and solar-driven reduction of carbon dioxide. Angew. Chem. Int. Ed. Engl. 2019, 58, 4601-4605. [CrossRef]

168. Yadav, R.K.; Baeg, J.O.; Oh, G.H.; Park, N.J.; Kong, K.J.; Kim, J.; Hwang, D.W.; Biswas, S.K. A photocatalyst-enzyme coupled artificial photosynthesis system for solar energy in production of formic acid from $\mathrm{CO}_{2}$. J. Am. Chem. Soc. 2012, 134, 11455-11461. [CrossRef]

169. Parkinson, B.A.; Weaver, P.F. Photoelectrochemical pumping of enzymatic $\mathrm{CO}_{2}$ reduction. Nature 1984, 309, 148-149. [CrossRef]

170. Kim, J.H.; Lee, S.H.; Lee, J.S.; Lee, M.; Park, C.B. Zn-containing porphyrin as a biomimetic light-harvesting molecule for biocatalyzed artificial photosynthesis. Chem. Commun. 2011, 47, 10227-10229. [CrossRef]

171. Ji, X.; Su, Z.; Wang, P.; Ma, G.; Zhang, S. Integration of artificial photosynthesis system for enhanced electronic energy-transfer efficacy: A case study for solar-energy driven bioconversion of carbon dioxide to methanol. Small 2016, 12, 4753-4762. [CrossRef]

172. Hofler, G.T.; Fernandez-Fueyo, E.; Pesic, M.; Younes, S.H.; Choi, E.G.; Kim, Y.H.; Urlacher, V.B.; Arends, I.; Hollmann, F. A photoenzymatic NADH regeneration system. ChemBioChem 2018, 19, 2344-2347. [CrossRef]

173. Yadav, R.K.; Kumar, A.; Park, N.-J.; Kong, K.-J.; Baeg, J.-O. A highly efficient covalent organic framework film photocatalyst for selective solar fuel production from $\mathrm{CO}_{2}$. J. Mater. Chem. A 2016, 4, 9413-9418. [CrossRef]

174. Park, C.B.; Lee, S.H.; Subramanian, E.; Kale, B.B.; Lee, S.M.; Baeg, J.O. Solar energy in production of L-glutamate through visible light active photocatalyst-Redox enzyme coupled bioreactor. Chem. Commun. 2008, 5423-5425. [CrossRef] [PubMed]

175. Nam, D.H.; Lee, S.H.; Park, C.B. CdTe, CdSe, and CdS nanocrystals for highly efficient regeneration of nicotinamide cofactor under visible light. Small 2010, 6, 922-926. [CrossRef] [PubMed]

176. Dibenedetto, A.; Stufano, P.; Macyk, W.; Baran, T.; Fragale, C.; Costa, M.; Aresta, M. Hybrid technologies for an enhanced carbon recycling based on the enzymatic reduction of $\mathrm{CO}_{2}$ to methanol in water: Chemical and photochemical NADH regeneration. ChemSusChem 2012, 5, 373-378. [CrossRef] [PubMed]

177. Ji, X.; Liu, C.; Wang, J.; Su, Z.; Ma, G.; Zhang, S. Integration of functionalized two-dimensional TaS 2 nanosheets and an electron mediator for more efficient biocatalyzed artificial photosynthesis. J. Mater. Chem. A 2017, 5, 5511-5522. [CrossRef]

178. Son, E.J.; Lee, Y.W.; Ko, J.W.; Park, C.B. Amorphous carbon nitride as a robust photocatalyst for biocatalytic solar-to-chemical conversion. ACS Sustain. Chem. Eng. 2018, 7, 2545-2552. [CrossRef]

179. Ryu, J.; Nam, D.H.; Lee, S.H.; Park, C.B. Biocatalytic photosynthesis with water as an electron donor. Chemistry 2014, 20, 12020-12025. [CrossRef]

180. Ganesan, V.; Sivanesan, D.; Yoon, S. Correlation between the structure and catalytic activity of [Cp* Rh(Substituted Bipyridine)] complexes for NADH regeneration. Inorg. Chem. 2017, 56, 1366-1374. [CrossRef]

181. Nam, D.H.; Kuk, S.K.; Choe, H.; Lee, S.; Ko, J.W.; Son, E.J.; Choi, E.-G.; Kim, Y.H.; Park, C.B. Enzymatic photosynthesis of formate from carbon dioxide coupled with highly efficient photoelectrochemical regeneration of nicotinamide cofactors. Green Chem. 2016, 18, 5989-5993. [CrossRef]

182. Lee, S.Y.; Lim, S.Y.; Seo, D.; Lee, J.-Y.; Chung, T.D. Light-driven highly selective conversion of $\mathrm{CO}_{2}$ to formate by electrosynthesized enzyme/cofactor thin film electrode. Adv. Energy Mater. 2016, 6, 1502207. [CrossRef]

183. Lee, Y.W.; Boonmongkolras, P.; Son, E.J.; Kim, J.; Lee, S.H.; Kuk, S.K.; Ko, J.W.; Shin, B.; Park, C.B. Unbiased biocatalytic solar-to-chemical conversion by $\mathrm{FeOOH} / \mathrm{BiVO}_{4} /$ perovskite tandem structure. Nat. Commun. 2018, 9, 4208. [CrossRef] [PubMed]

184. Kuk, S.K.; Ham, Y.; Gopinath, K.; Boonmongkolras, P.; Lee, Y.; Lee, Y.W.; Kondaveeti, S.; Ahn, C.; Shin, B.; Lee, J.K.; et al. Continuous 3D titanium nitride nanoshell structure for solar-driven unbiased biocatalytic $\mathrm{CO}_{2}$ reduction. Adv. Energy Mater. 2019, 9, 1900029. [CrossRef] 
185. Yadav, R.K.; Oh, G.H.; Park, N.J.; Kumar, A.; Kong, K.J.; Baeg, J.O. Highly selective solar-driven methanol from $\mathrm{CO}_{2}$ by a photocatalyst/biocatalyst integrated system. J. Am. Chem. Soc. 2014, 136, 16728-16731. [CrossRef] [PubMed]

186. Kuk, S.K.; Singh, R.K.; Nam, D.H.; Singh, R.; Lee, J.K.; Park, C.B. Photoelectrochemical reduction of carbon dioxide to methanol through a highly efficient enzyme cascade. Angew. Chem. Int. Ed. Engl. 2017, 56, 3827-3832. [CrossRef] [PubMed]

187. Roth, L.E.; Nguyen, J.C.; Tezcan, F.A. ATP- and iron-protein-independent activation of nitrogenase catalysis by light. J. Am. Chem. Soc. 2010, 132, 13672-13674. [CrossRef]

188. Roth, L.E.; Tezcan, F.A. ATP-uncoupled, six-electron photoreduction of hydrogen cyanide to methane by the molybdenum-iron protein. J. Am. Chem. Soc. 2012, 134, 8416-8419. [CrossRef]

189. Brown, K.A.; Harris, D.F.; Wilker, M.B.; Rasmussen, A.; Khadka, N.; Hamby, H.; Keable, S.; Dukovic, G.; Peters, J.W.; Seefeldt, L.C.; et al. Light-driven dinitrogen reduction catalyzed by a CdS: Nitrogenase MoFe protein biohybrid. Science 2016, 352, 448-450. [CrossRef]

(C) 2020 by the authors. Licensee MDPI, Basel, Switzerland. This article is an open access article distributed under the terms and conditions of the Creative Commons Attribution (CC BY) license (http://creativecommons.org/licenses/by/4.0/). 